\title{
UMLD
}

\section{THES I S}

$378.7 M 71$ XL49 

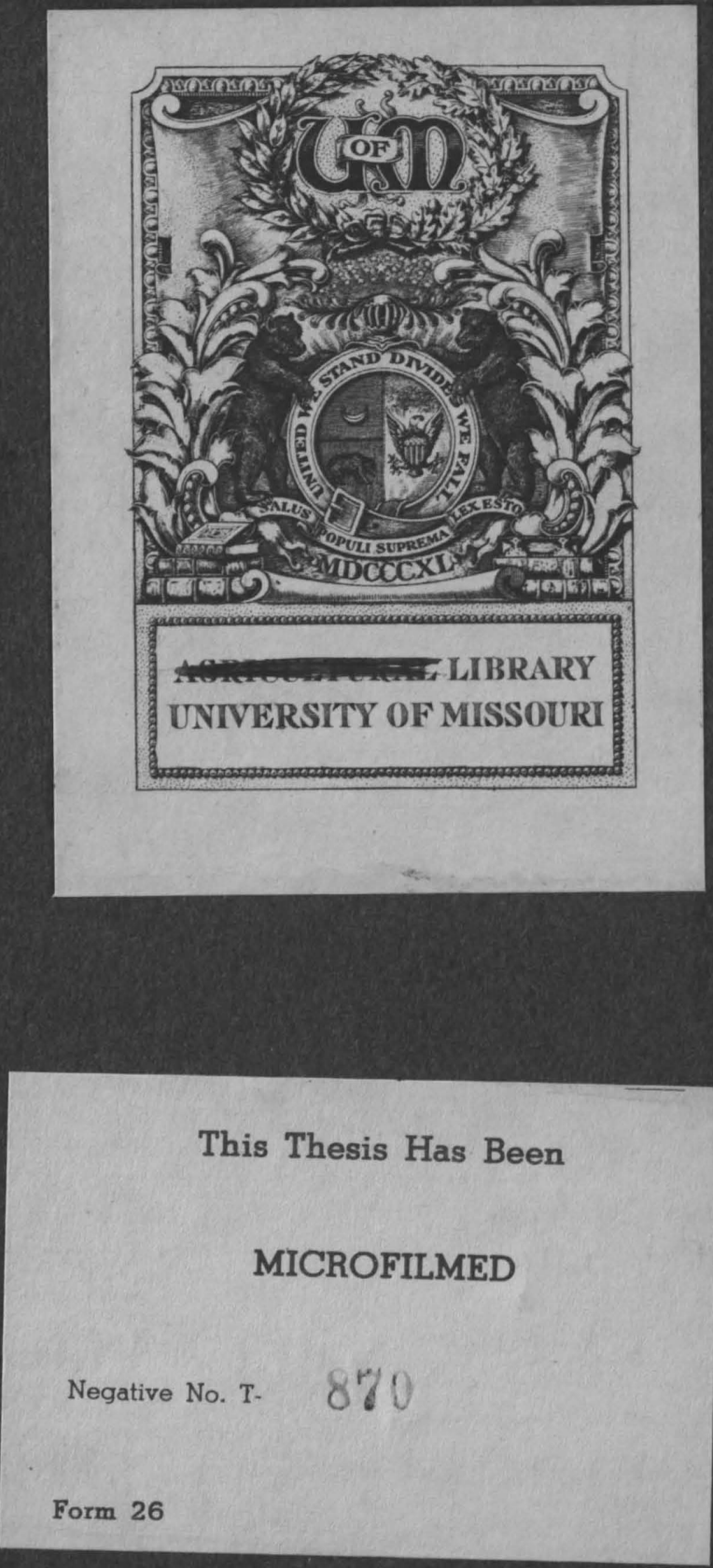




A STUDY OF THE PHYSICAL AND CHEIICAI PROPERTIES OF THE SOII AS INFIUENCED BY CONPEA CULTURE

\section{by}

Carlos Amie Iي Clair, B. S. (Agrioulture)

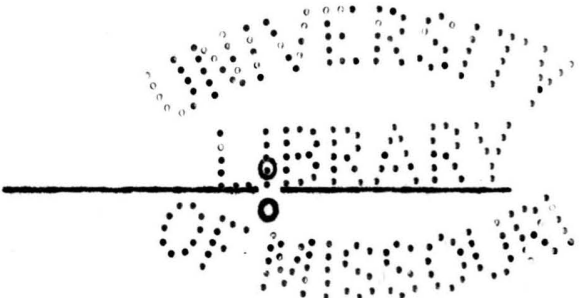

SUBMITTED IN PART IAL FULFIILIENT OF THE

REQUIREIENTS FOR THE DEGREE OF

MASTER OF ARTS

in the

GRADUATE - SCHOOI

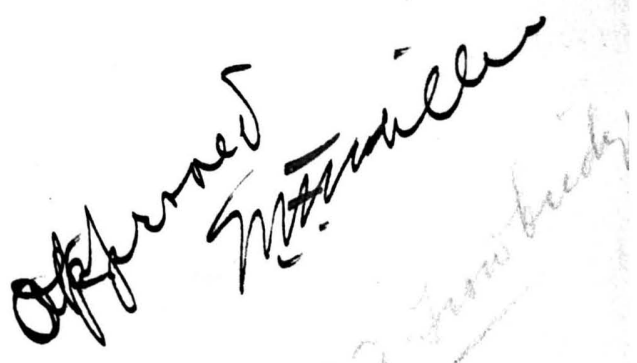

of the

UNIVERSITY OF MISSOURI

1913 



\section{BIBIIOGRAPHY}

Stewart, R. and J. E. Graves, Bulletins 106 and 110 of the Utah Station, on "The Production and Hovement of Nitric Nitrogen".

Philz, F. Ztschr. Landw. Versuchsw. Osten., 14 (1911), No. $10, \mathrm{pp} .1150-1210$.

Iyon, T. I. and Bizzell, J. A., Journal Franklin Inst., 171 (1911), Nos. 1, pp. 1-16; 2, pp. 205-220, dgms 4.

Bulletin No. 326, Cornell Station, Water Soluble llatter

in So1ls Sterilized and Reinoculated, p. 224.

Buohler, A. - Clel et Terre, March 1896. XVII, p. 22.

Wollney, E. - Der Einfluss Pflanzendecke und Beschattung, p. 165 .

U. S. Department of Agricultare, Bureau of Soils, Bulletin N10. 40, p. 36 .

Thorne, C. B., Ohio Station, Bulletin No. 176, Soll

Extract Studies.

Wheeler, H. J. and Breazeal, J. F., Rhode Island Station, 18th Annual Report, pp. 286-323, "On the Cause of the Unproductivity in a Rhode Island So1l". 

A STUDY OF THE PHYSICAL AND CHEMICAL PROPERTIES OF SOIL

AS INFLUENCED BY COWPEA CULTURE

\section{INTRODUCTION}

In the past twenty-five years much experimental work has been done with cowpeas, in relation to cultural methods, fertilization, and variety tests, but practically nothing has been written with regard to the direct effect of the plant upon the so11. It has been supposed that the peas are beneficial to a companion crop as, for example, corn. Some have expressed the bellef that cowpeas are capable of producing a loosening effect upon the soll. Still others claim that the continuous cropping of land to this plant alone, or as a catch crop with wheat, results in an effect deleterious to the best growth of either wheat or peas. As to actual experimental data on the se subjects, however, nothing authentic has been discovered.

\section{WORK OF OTHER INVESTIGATORS}

An exhaustive study of research literature revealed that previous work along these particular lines has been exceedingly limited. The following experiments bear only indirectly on the work of this thesis but are undoubtedly worthy of consideration. The historical data is grouped in three divisions. The first includes references dealing with the problem of nitric nitrogen in the soll, the second with the effect of ahade upon the soll and the third with the effect of continuous cropping. 

HISTORICAT

Nitric Nitrogen in the Soil

F. Philz, (Ztschr. Iandiw. Versuchsw. Ost., 14 (1911), No. 10, pp. 1150-1210), found that the nitrogen production in the soil, per unit area, was greater where legumes and cereals were grown together on the same plot than was the sum of the nitrogen production by the crops when grown alone on separate plots.

T. I. Iyon and J. A. Bizzell, (Journal Franklin Inst., 171 (1911), Nos. 1, pp. 1-16; 2, pp. 205-220, dgms 4), found that during the most active growing period of the corn crop nitrates were higher under corn than in cultivated soil bearing no crop. This phenomena was explained by the fact that nitrification is stimulated by some processes connected with the active growth and absorbing functions of the plants. Nitrates did not increase in cropped plots at the end of the season as they did in uncropped plots. On uncropped soil an increase of moisture in September was accompanied by a marked increase in nitrate accumulation.

R. Stewart and J. E. Graves, (Bulletins 106 and 110 of the Utah Station, on "The Production and Movement of Nitric Nitrogen"), found after extensive study, that there exists a pronounced variation in nitric nitrogen content of soils from foot to foot during the season due to water movement, variation in nitrification, feeding of plants and the fixation of nitric nitrogen in the form of insoluble protein by 

mioro organisms.

In cropped land there was always less nitrogen in the soil during the fall than in the spring. In fallow soils, on the other hand, more nitrogen was found in the fall than in the spring. Alfalfa left less nitrogen in the soil in the nitric form than did either oats or potatoes. F. H. King of the Wisconsin Station measured the nitrates under corn at frequent intervals throughout the season and produced the following curve.

Parts per million of $\mathrm{NO}_{3}$

80

60

40

20

Time
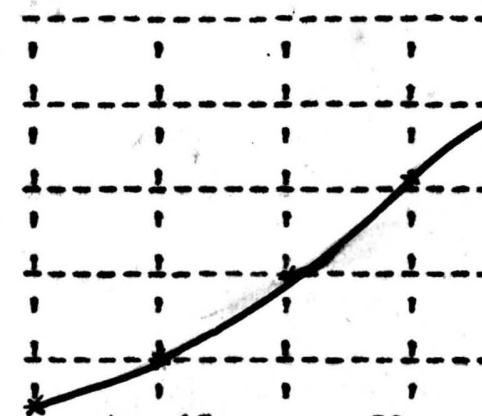

Way
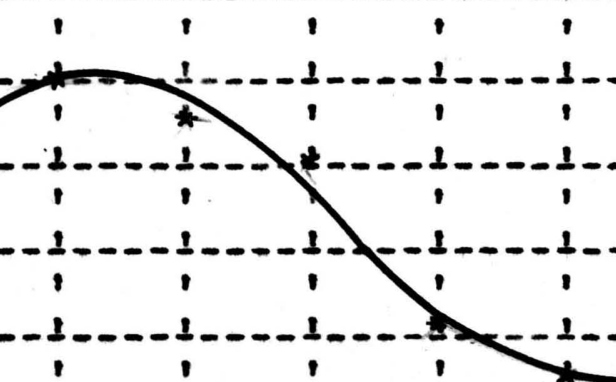

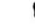
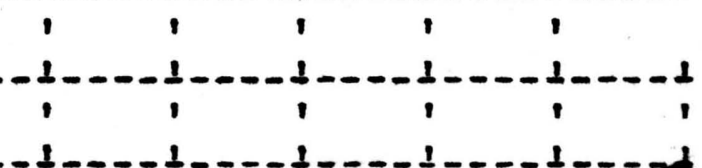

by night under the shaded plot was very slight, being under 2 degrees Centigrade which explains the effectiveness of a wind break in preventing injury by frost. In rainy weather the variation of temperature either by day or by night was much smaller.

The relative evaporation from plots throughout the test was as follows:

Treatment

Per cent Evaporation No shade. . . . . . . . . 100

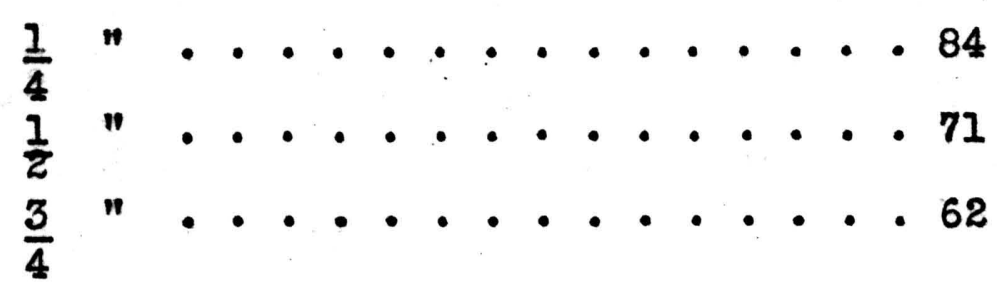

E. Wollney, (Der Einfluss Pflanzendecke und Beschattung, page 165), reports that the shade of crops on land has little or no tendency to increase the looseness of a soll, but his data shows that a crop on the land, be it cereal or legume, partially prevents the land from becoming compact. He has proven that not alone is this effect due to elimination of the effects of beating rains and sunlight thereafter, but to a greatly increased bacterlal activity on cropped land. The bacteria thrive better in the moderate shade afforded by the plants, produce more humus and thus improve the soil structure. The author gives definite experimental data to substantiate his conclusions.

\section{Effect of Continuous Cropping}

The United States Department of Agriculture, Bureau of So1ls, has shown in bulletin 40 , page 36 , that excreta of 

Wheat is harmful to succeeding crops of the same plant and that cowpeas following wheat are also somethat toric to the wheat and much more $s 0$ to more nearly related plants. of course, these conclusions were drawn from plant house. tests which were conducted as follows:

The wheat seedlings were grown in sterile quartz sand or water culture and, after running a series of days or woeks the crop was harvested, when wheat or cowpeas were again planted in the ame culture jar or flask. The growth of seodlings so treated as compared with others grown in nontoxic distilled water was the basis for their comparison. As an index to plant growth, they measured daily transpiration which they found amounted to from two to ten times the weight of the seedling. After growing a number of seodlings under such conditions the extract remaining in the culture bottle or pot is distilled and further cultures made of the distillate and of the residue. By determining whether the plants show stunting elther in the distillate or the residue, the volatile or non-volatile character of the deleterious body is learned. In this way they have succeeded in isolating and identifying many toxic bodies among which di-hydroxysteario acid and Plcoline carboxulfic acid may be mentioned. That toxic bodies are most all of an organic nature, may be show by evaporating the soll extract to dryness and ignit1ng. The residue when again taken up with water no longer retains its deleterious effect. Absorbent materials such as carbon black, ferric hydrate, $\mathrm{CaSO}_{4}$, and $\mathrm{CaCO}_{3}$ have the ability to remove toxic bodies from solution. It was 

further discovered that a soll found to be toxic was more deleterious to plants grown upon it than an extract of some. This is explained by the supposition that, as toxic bodies are not readily soluble, there would be a much greater amount ready for action in the soil than in its extract. That the toxicity of the soils tested was not due to their acidity was shown by the fact that non-toxic water made equally acid with mineral acids had no bad effects upon the plants grown in 1 t.

$$
\text { C. E. Thorne, Ohio Station, (Bulletin 10. 176), }
$$
working in conjunction with the United States Bureau of Solls, found that while every soil they examined which exhibited toxic properties was acid in nature, all acid soils were not toxic.

H. J. Wheeler and J. F. Breazel, Rhode Island Station, (18th Annual Report, pages 286-323), checks identically with the findings of the Ohio station.

T. Iyttleton Iyon and James A. Bizzell, Cornell Station (Bulletin No. 326), in a study of water soluble matter in soils sterilized and reinoculated, report that of two soils studied in the laboratory, soil (2) was very poor in spite of the fact that it contained as much organic matter and nutrient materials as did soil (I) which was remarkably good. The inability of the former soil to rid itself of toxic material formed by the steaming process of this experiment indicates that a similar condition causes its sterility in the field. 

SCOPE OF PROBLEUS

The soll of the station fields, upon which all experiments were run, analyzed as a silt loam. (See table A below,) The surface from $0^{\prime \prime}-8^{n}$ is a gray to brownish silt loam, from below the surface 8"-24" it grades heavier and is dark red in color, and from $24 "-48$ " it becomes more granular, contains some sand and is of a light yellowish tinge.

\title{
TABIE A
}

\begin{abstract}
MECHANICAL ANALYSIS OF SOIL
\end{abstract}
O" TO 8" OF EXPE RIMENTAI, PLOTS

\begin{tabular}{|c|c|c|c|c|c|c|c|}
\hline $\begin{array}{l}\text { Volatile } \\
\text { Matter }\end{array}$ & $\begin{array}{l}\text { :Fine } \\
\text { :Gravel. } \\
\text { : }\end{array}$ & $\begin{array}{l}\text { :Coarse } \\
\text { : Sand } \\
\text { : }\end{array}$ & $\begin{array}{l}\text { :Medium } \\
\text { :Sand } \\
\text { : }\end{array}$ & $\begin{array}{l}\text { :Fine } \\
\text { : Sand } \\
\text { : }\end{array}$ & $\begin{array}{l}\text { Very } \\
\text { :Fine : Silt } \\
\text { :Sand : }\end{array}$ & $\begin{array}{l} \\
: \text { Clay } \\
\end{array}$ & : \\
\hline$\frac{\%}{4.91}$ & $\therefore \quad \%$ & $: \%$ & $\therefore \quad \%$ & & $\div \%: \%$ & $\div \%$ & $: 9$ \\
\hline
\end{tabular}

The main lines of investigation in this the sis were a study of the physical and chemical effects of cowpeas upon a soil when grown alone, when grown as a companion crop with corn and when grown as a catch crop after wheat. In adition to the direct study of the main problems, extensive observations were also made of the molsture contents of all plots and the relation of precipitation to orop removal. In conjunction $\mathrm{wi}$ th Mr. P. I. Gainey, working in Soil Bacter10logy, much data was secured relative to the bacterial flora under the various treatments.

All the problems above mentioned suggested themselves through numerous inquiries made by farmers and by general observations on experiment station fields. Time and 

again it has been reported that land seeded to cowpeas was much looser in the fall than adjacent plots not planted to peas. Also that, because of the extreme looseness of the soil after cowpeas, wheat following does not do well.' Some have said that cowpeas, as a companion with corn, will benefit the latter; while others report that the corn yield is cut by the dual cropping system. Then, too, the question arose as to whether it made any difference in yield of ef ther orop if the cowpeas were drilled in the row with the com, or planted in between the rows at the last cultivation. Lastly, as to the advisability of the common practice of continuous cropping of land to a rotation of whe at and cowpeas, little was definitely known save that where such a system is in vogue signs of a corpea sickmess is apparent in some places.

\section{OB JECT}

Because of the apparent lack of data on these subjects of importance, this thesis was begun in september 1911.

\section{PIAN OF THE WORK}

From September 1911 until the Spring of 1912, the work consisted mainly in formulating plans and making preliminary tests for a basis upon which to lay the final scope of the work. The work eventually decided upon, as indicated in the introduction, was the physical and chemical properties of the soil as influenced by compea culture. This will be described in three parts as follows: Part I, Effect 

of cowpeas as a companion crop vith corn; Part II, Effect of cowpeas on soil structure; Part III, Effect of continuous use of cowpeas following wheat.

\section{PART I.}

In Part I, the relation of cowpeas in corn to soil moisture and nitrate content, uniform, level piece of land was la1d out in three $1 / 26$ acre plots. (See F1g. I, Part I, page 16). Plots number I and. II were arilled to yellow dent corn after carefully preparing the soll, while plot number III was drilled to the same amount of corn together with black cowpeas in the proportion of two parts of corn to three parts of peas. The season was late this year for lissouri and the crop was not put in until May 25th, 1912. On llay 29th, 1912, all plots were harrowed. Later the corn and peas were replanted so that as near a perfect stand as possible was secured. The woeds were sorupulously removed from time to time by frequent cultivations and even hand hooings. Whenever this was done, all plots were worked on the same day and treated 1dentically the same. At the last cultivation of corn, the same amount of peas as used on plot III vere planted in plot II between rows of corn. This was accomplishod by using a one horse wheat drill with every other tube closed. Thus there were three rows of peas between every two rows of corn. The empty drill was run through the other plots at this time so as to eliminate error through 1ts mulch effect. The peas planted with the corn on plot III had not spread enough to be injured by this treatment. 

Nitrate and moisture determinations were made at the following periods:
(a) At planting time.
(b) At last cultivation.
(c) At tasseling time.
(d) At harvest time.

Observations were made from time to time as to the maturity of the corn on all plots and the yleld of same was secured at the end of the season.

\section{PART II.}

On June 17th, 1912, another uniform strip of land which had been in small grain the previous year was selected and divided into five $1 / 62$ acre plots. (See Fig. I, Part II, Page 25) Plots I and II were scraped. with a hoe to make them free of weeds and debris. Plots III, IV and $V$ were carefully spaded to a depth of eight inches. A series of samples for molsture and nitrate analysis were taken over the entire area to a depth of three feet, at this time. Just before planting to peas, compactness tests were made with an especially devised instrument (See Fig. III, Part II, page 28) on plots plowed and unplowed. On June 8th, 1912, plots II and III were drilled to black compeas and artificlal shade was arranged on plot IV (See F1g. II, Part II, page 26). The three plots uncropped were kept free of weeds from time to time by scraping them off with a hoo but no further cultivation was given. At the close of the growing season, compactness of all plots was again measured and another series 

of soil samples secured for nitrate, moisture, and bacterial studies.

\section{PART III}

For this experiment, two adjacent plots were secured, one of which had been cropped to wheat followed by a fall catch crop of cowpeas for a series of twelve years, the other to a rotation of corm, oats, wheat and legume for a similar length of time. (See Fig. I, Part III, page 40.) The former will be called plot "A" and the latter plot "B" in the course of this discussion. Both plots vere in wheat when first samples of soil for moisture and other studies were taken, June 8th, 1912. It was the plan of the experiment to take samples respectively for special analysis of molsture, nitrate and bacterial count at the following perlods:
(a) In the spring.
(b) At wheat harvest.
(c) In the late fall.

Unfortunately a complete analysis of this soil at the beginning of the experiment, eight years ago, was not available but nevertheless, assuming that both plots were identical at that time, it was planned to compare the present supply of plant food. Thus it was hoped might be determined the cause for the continually poorer crops on the continuousIy cropped plot. Treatment was made of the soil from each plot in pot culture as was the extract of the same studied in water culture experiments. As yet, however, work has not 

progressed sufficiently in this line to warrant more than a brief discussion in this thesis.

\section{PRELIMINARY DATA.}

Before deciding apon the number of cores it would be necessary to take from each plot to warrant an authentic analysis representative of the soil under consideration, nitrate determinations of many individual borings were made. It was found that the average analysis of at least six borings gave a result wi thin the limit of experimental error for the mothod used. In adition to this, a composite sample was made of the $\mathrm{s}$ ix cores, which gave on analysis, as seen in the following table, a result as accurate as that obtained by averaging the individual analysis. Hence, all future data reported for chemical analysis will be from a composite of from six to eight samples taken from each plot. (See Table I, page 13) 



\section{TABIE I}

NITRATES IN PARTS PER MILIION OF OVEN DRY SOII

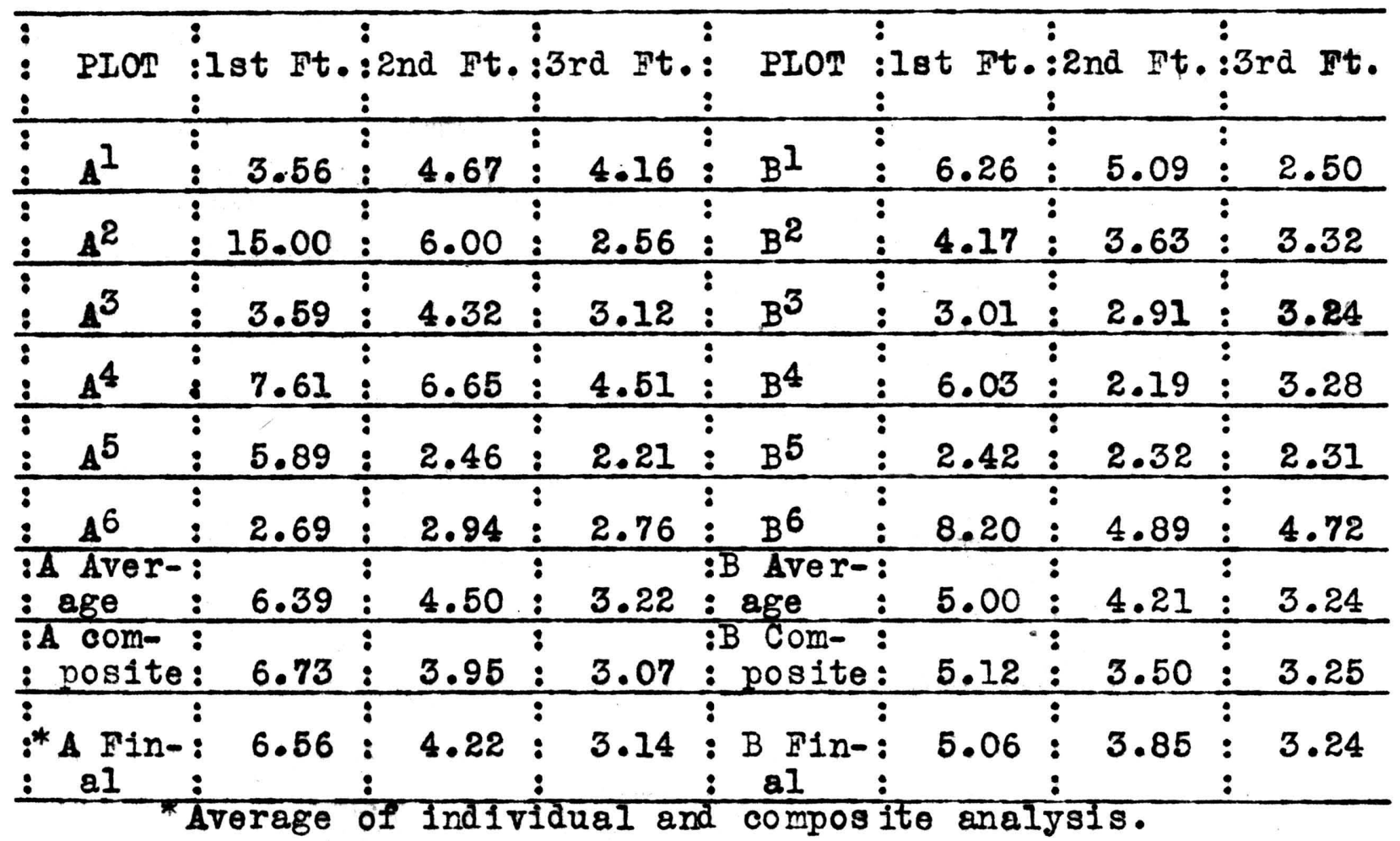

The individual samples from which the above tabulatod data was secured and, in fact, al I the samples secured in this entire rork were taken four feet deep rith an inch and a half soll auger. The soll from each foot ras placed in a separate container and taken to the laboratory. For chemical analysis the soil was at once aried in the oven at 50 degrees Centigrade so as to prevent continuance of bacterial activity, ground in a mortar and sent through a 60 mesh sieve. A composite was made by carefully mixing on a rubber oloth and finally riffling.

In order to still further insure the representativeness of the samples from a given plot, the following plan was devised to distribute the borings, with especial reference to 

corn plots. (See Fig. A below.)

\section{F1g. A}

$45 \mathrm{ft}$.

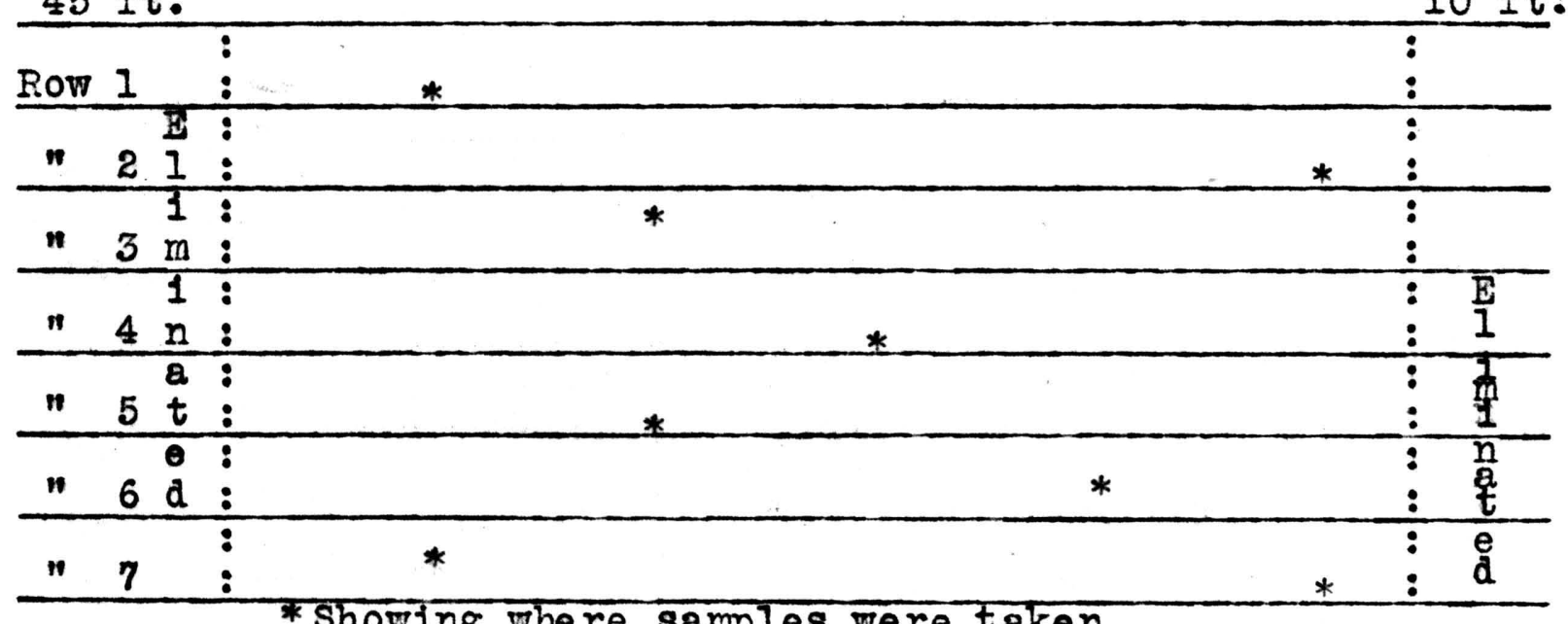

Showing where samples were taken

Originally it vas planned to secure samples only to the third foot because of the tenacity of the heavy clay subsoil below, but later in the season it was found possible to obtain an additional foot.

Official methods were followed in all analytical work except where othervise stated.

In like manner the number of cores necessary to make a representative moisture determination was ascertained. The same general scheme as shown in Fig. A above was used when securing moisture samples, taking care, of course, not to let two borings come too close to each other. Noisture samples vere placed in tared metal cans and taken to the laboratory as soon as possible. A net weight was at once secured and then the covers removed and the samples dried in an oven at 105 degrees Centigrade until constant weight was obtained. 

Table II below gives the data obtained on June 14th, 1912, on a test plot of average size used.

\section{TABIE II}

* per cent of hoisture over ail plats.

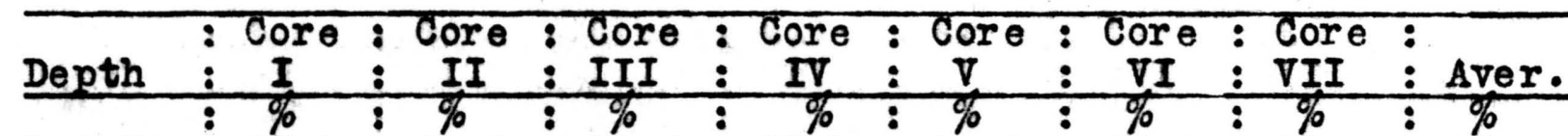

Ist Ft.: $25.1: 20.3: 24.5: 25.1: 26.4: 23.4: 22.2: 23.8$

2nd Ft. : $30.1: 29.8: 30.9: 30.5: 30.0: 30.3: 29.9: 30.2$
3rd Ft.: $27.1: 27.1: 28.5: 27.0: 27.0: 27.2: 24.8: 27.1$ Per cent of molsture always reported on the oven dry basio.

A study of this table reveals the fact that six or more samples of the first foot, five or more of the second and four or more of the third or fourth foot when ave raged together give, within one per cent error, the amount of moisture in the soll at the respective depth. Upon this basis of calculation all future moisture data will be reported.

Experimental work upon a shade device for Plot IV, F1g. I, Part II, revealed the fact that a window soreen tightly stretched over a frame and covered with a thin grade of black cheose cloth, would per mit rain to pass through without much hinderance but shut out the direct rays of the sun, thus providing the desired screen effect. 

EXPERIMENTAI DATA

PART I

EFFECT UPON SOIL WHERE COWPEAS ARE GROTN

AS A COITANION CROP WITH CORN

F1g. I.

Showing looation and arrangement of plots in Part I.

HIILCREST AVENUE

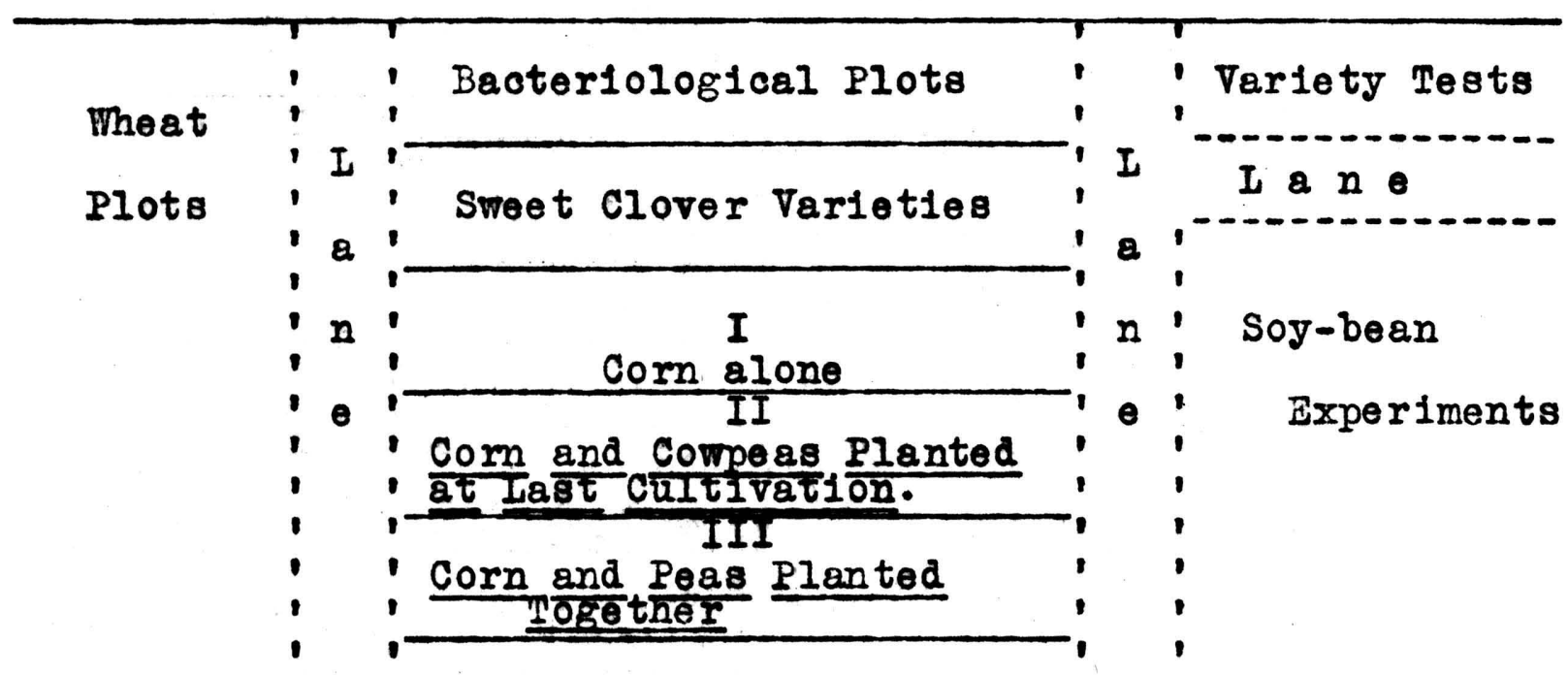

In the work with the inter-relationship of cowpeas and corn, it was found that at last cultivation the $\mathrm{NO}_{3}$ content for the first three feet had greatly increased over what 1t was at the beginning of the experiment on June 20th, 1912 . (Compare Tables IA and IB)

TABIE IA.

PARTS PER UIILIUN OF HO3 PER GRAII OF DRY SOIL

June 20th, 1912. Beginning of Experiment Treatment : lst Ft. : 2nd Ft. : 3rd Ft. Al1 plots: $9.11: 5.59: 5.25$ 

TABIE IB

PARTS PER MIILION OF NO 3 PER GRAM OF DRY SOIL

July 11, 1912 At Last Cultivation Treatment

Corn Alone Corn with Cowpeas At Last Cultivation: Corn with Cowpeas Planted Together

From these tables it is evident that nitrification has increased in all plots quite uniformly and, although the re is a slight variation, we can say it is well within the limit of experimental error. The increased amount of $\mathrm{NO}_{3}$ in the soll on July 11, 1912, must be solely because of cultivation and increased bacterial activity due to seasonal stimulus. This conclusion is upheld by the findings of F. H. King with regard to nitrates under corn as previously sighted. (See, Work of Other Investigators, under Historical Data, page 3)

\section{TABIE II}

PARTS PER IILIION OF NO3 PER GRAM OF DRY SOIL

August 2, 1912 At Tasseling

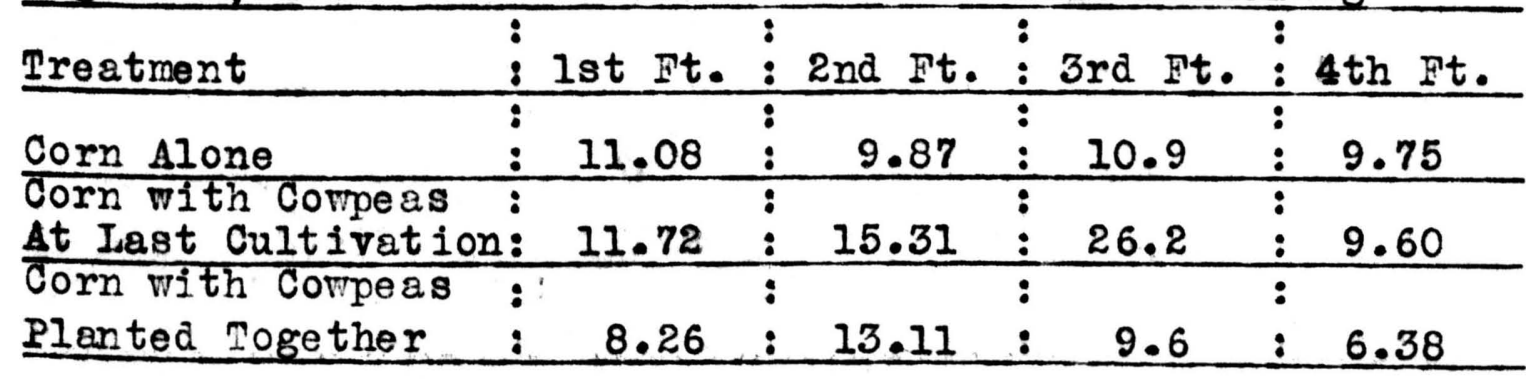

Here we see a complication of data which is somewhat dificult to explain. However, the plot to corn and 

compeas at last cultivation, in pounds per acre top three feet of soll, has most nitrates; corn sown alone ranks next and corn and compeas planted together last. By compering data of Table II with nitrate analysis for June 20th, considering of course only the first three feet of soil, it is seen that under all treatments there is more $\mathrm{NO}_{3}$ in the soil in all plots at this time than was the case in the spring. Comparing what was present in the soil at last cultivation (Table IB) with the amount present to date, it is seen that there are less nitrates present on all plots. In that the nitric nitrogen content of the fourth foot is seemingly constant, it may be therefore concluded that the plots are exhausting the available nitrogen supply at this period of heavy growth. The peas had just begun to make growth and were not supplying nitrogen for themselves as jet as the amount left in the soil reveals.

TABIE III

PARTS PER MIIIION OF NOZ PER GRAII OF DRY SOII

November 12,1912 At Harvest

\begin{tabular}{|c|c|c|c|c|c|c|}
\hline Treatment & $\overline{:}$ & t Ft. & $\vdots$ & nd Ft. & 3rd Ft. & $: 4$ th Ft. \\
\hline Corn Alone & $:$ & 9.54 & $\vdots$ & 6.09 & 6.86 & 4.38 \\
\hline $\begin{array}{l}\text { Corm and Cowpeas } \\
\text { at Iast cultivation }\end{array}$ & $\div$ & 10.45 & $\vdots$ & 7.50 & $\vdots$ & 3.61 \\
\hline Corn and Cowpeas & $\bar{\vdots}$ & & $:$ & & $:$ & $:$ \\
\hline Planted Together & : & 8.91 & : & 8.81 & 5.999 & 4.21 \\
\hline
\end{tabular}



Comparing the different treatments one with the other at harvest time, it is found that practically the same amount of nitrogen is left in the soil in every case. Howover, on November 12th, there are less nitrates present than at tasseling time or at last cultivation. At some time between August $2 d$ and harvest of crop the removal of nitrates in the soil mas have exceeded the production of same by bacteria. Table III then Lrepresents a point where the production is again on the increase over the removal by regetation and leaching. The periods of nitrate study were too greatly separated by time intervals to plot a curve which could be compared with the observations of seasonal change of nitrate content of soil under corn shown by king. (See Historical Data). Yet, for the most pert it will be seen from the above comparisons that, for the plot planted to corn alone at least, there is a striking agreement with previous findings.

Figuring that the first foot of this soil under conslderation over an acre weighs $3,000,000$, the second foot $3,500,000$, and the third foot $4,000,000$ pounds and that there is no appreciable witharawel of nitric nitrogen from below the third foot on the solls studied, the following table is presented for consideration.

\section{TABLE IV}

POUNDS OF NITROGEN (NITRIC) IN

TOP RCRE THREE FEET OF SOIL

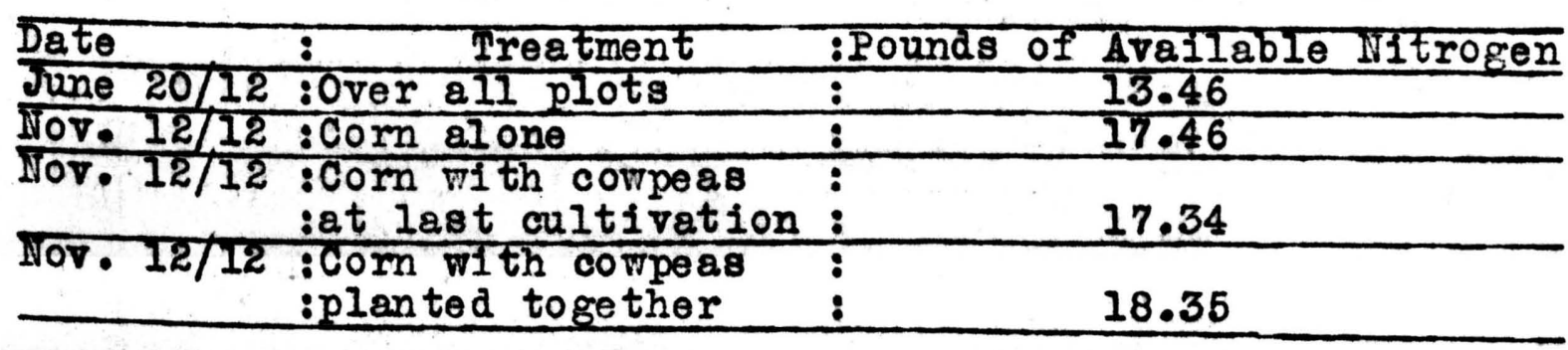



Table IV reveals the fact that the compeas in the corn did not use any more of the available nitrogen than did the corn alone. In fact, even more nitrogen seemed to be left in the soil where peas were planted with the corn at planting time than under any other treatment. In order to check this finding, nitrate determinations will be made again in the spring (1913) on each plot to determine which treatment offers most arailable nitrogen to the orop following.

Now by turning to a consideration of the water content of the same plots and comparing with samples taken in the same way at the various periods, the following tables are produced.

\section{TABIE V}

PER CENT OF WATER IN SOIL

June 20, 1912 Treatment Over all Plots At Beginning of Experiment

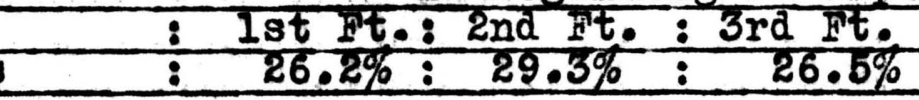

TABIE VI

PER CENT OF WATER IN SOIL

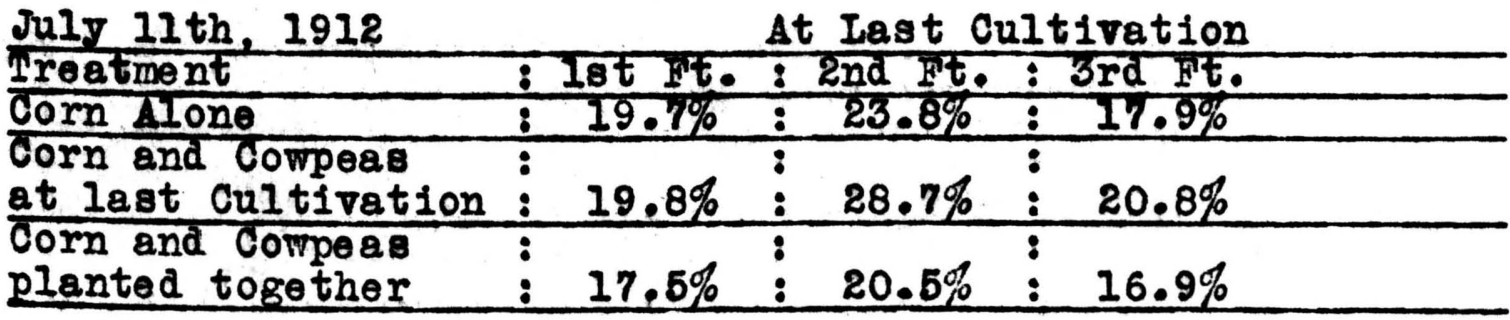

Here it will be seen that the cowpeas with corn at planting time have used considerably more water than the plot to corm alone up to July 11th, 1912, but the water has been removed from all depths considered so that the general relation in the respective depths under the corm and peas remeins 

much as it at the beginning of the experiment. The spring was very dry this jear and this together with the fact that the cowpeas were drawing heavily on the soil moisture at this time accounts for the results in the above table. Cowpeas planted in plot Number II at this time and the continued drought as shown in Table IX, page 23, resulted in a slight set back to the peas planted at last cultivation. They did survive horever, and made almost a perfect stand. The peas on Plot III seemed to have made normal growth In spite of the ary weather, for on August 1, 1912, they almost completely covered the space between the rows. Absolutely no stunting effect of the corn was observed under any trea tment. Nevertheless, the corn planted alone seemed to be maturing somewhat earlier. Moisture in the soll at tasseling time is tabulated in Table VII.

\section{TABIE VII}

PER CENT OF MOISTURE IN THE SOII.

\begin{tabular}{|c|c|c|c|c|}
\hline 210 & & & & \\
\hline$\frac{\text { Treatment }}{\text { corn Alone (I) }}$ & $\frac{18 t \text { Ft. }}{: 11.6 \%}$ & $\frac{\text { 2nd Ft. }}{: 14.8 \%}$ & $\div$ 3rd Ft. & $\therefore 4 t h \mathrm{Ft}$ \\
\hline $\begin{array}{l}\text { Corn Planted with } \\
\text { Cowpeas at last Cul. }\end{array}$ & $12.7 \%$ & $12.8 \%$ & $18.2 \%$ & $17.2 \%$ \\
\hline $\begin{array}{l}\text { Orn Planted with } \\
\text { owpeas at plant ing }\end{array}$ & $11.0 \%$ & $17.5 \%$ & $17.4 \%$ & $19.5 \%$ \\
\hline
\end{tabular}

Thus on the whole, to date, when only the first three feet of soil in each plot is considered, It is seen that the plot to corn alone conserved least moisture, corn with cowpeas at last cultivation next, and corn and compeas planted together most. It 18 also evident that the plot to peas at last cultivation is using most of its water supply from the second foot 

of soil wherein the young compea roots at this time are just getting a foot hold. Nevertheless, when we consider the amount of water used down to four feet it would seem that cowpeas are, by reason of their shading effect or otherwise, leaving more water in the soil. With the amount of water left in the soil at this time by corn planted alone taken as 100, the ration stands for the other plots as follows:

Corn and cowpeas planted at last cultivation....115

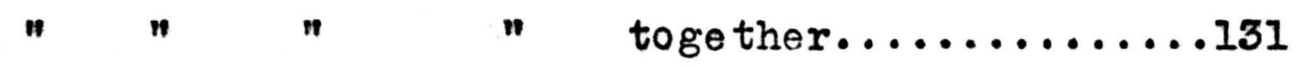

This data is further evidenced by the fact that the corn on the plots to cowpeas showed no tendency to fire, while where corn was planted al one the lower leaves, at least three, had already turned yellow and ary. From what has been previously said, we could not attribute this phenomena to the difference in nitrate content of the soil ander each treatment, so it must be due to moisture differences or to other variable factors.

\section{TABIE VIII}

\section{PER CENT OF MOISTURE IN SOII}

November 12 th, 1912. Treatment Corn Alone Corn with cowpe as Planted at Iast Cultivation Corn with cowpeas Planted Together At Harvest : Ist Ft.: 2nd Ft.: 3rd Ft.: 4 th Ft. $: 25.87 \%: 26.70 \%: 19.70 \%: 20.40 \%$

\begin{tabular}{l}
$: 26.30 \%: 23.20 \%: 18.10 \%: 17.40 \%$ \\
\hline $23.40 \%: 26.20 \%: 19.40 \%: 17.30 \%$
\end{tabular}

Again, considering only the first three feet of soil, we can see by a comparison of the above table with that of Table V, page 20, taken at the planting time, that, through the season as a whole corn alone is only slightly less exhaustive 

of soil moisture than where corn and cowpeas are planted either together at planting time, or corm with cowpeas at the last cultivation.

To represent even more vividly the fluctuation of soil moisture content throughout the season under the various treatments we present the following tables.

TABLE IX

* TONS OF WATER IN TOP THREe FEET OF SOIL

DURING GROWING SEASON

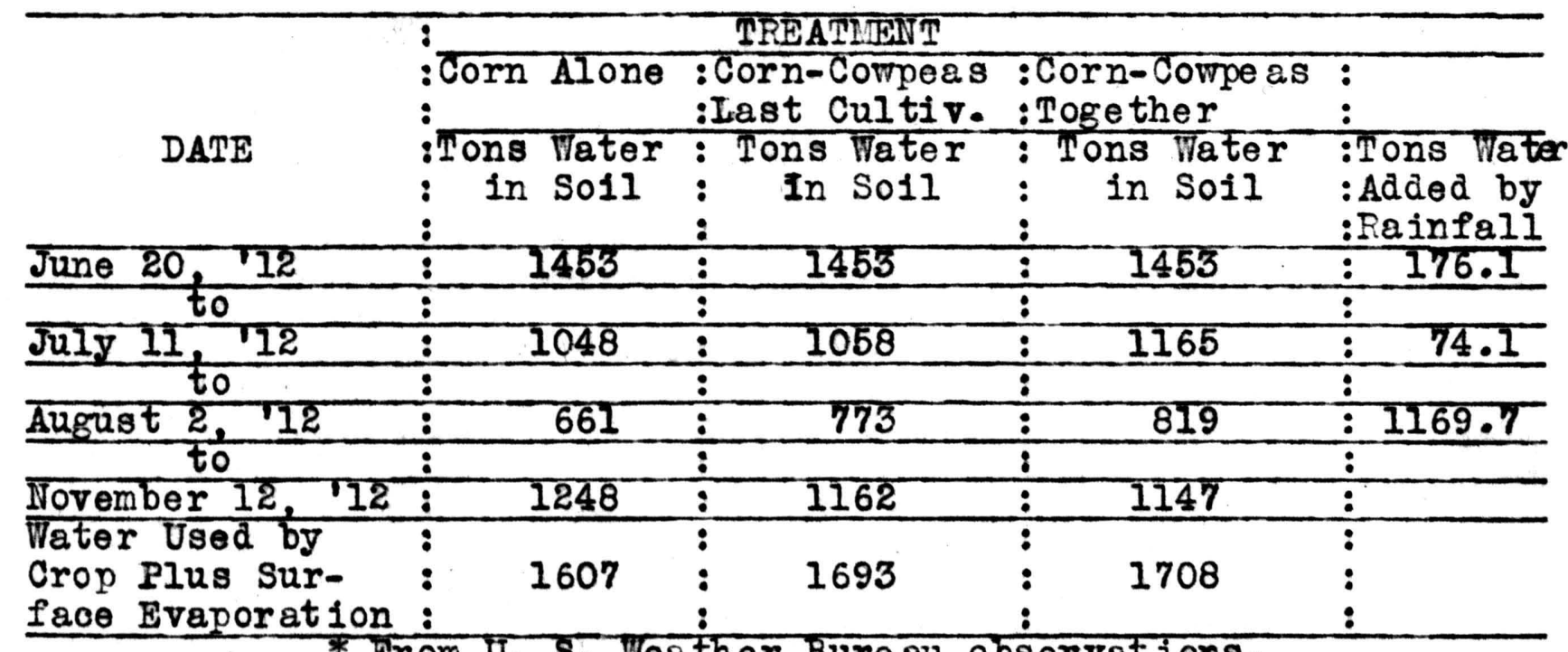

* From U. S. Weather Bureau observations.

TABIE $\mathrm{X}$

* mons of water used under various treatients during

SEASON

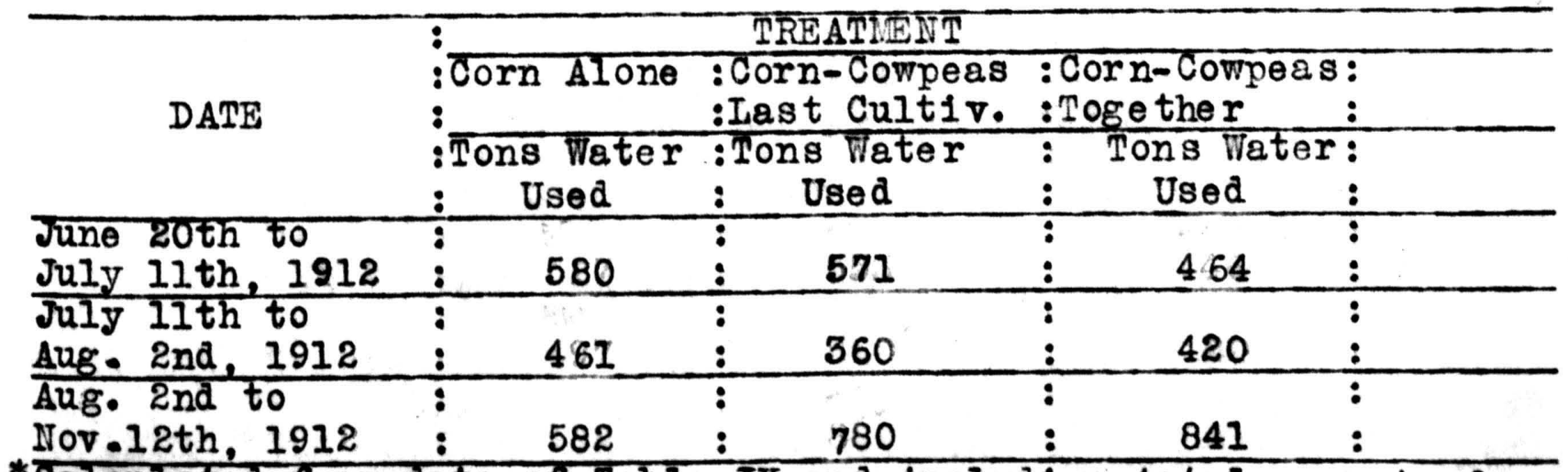

* calculated from data of Table IX and including total amount of water used by the crop and lost through surface evaporation. 

A study of Table IX reveals the fact that the entire season corn, considered as a whole, with peas planted as a companion crop are, as was stated before, slightly more exhaustive of soil moisture than corn alone. Table $\mathrm{X}$, however, shows that the effect of the companion crop must be to prevent evaporation of water from the soil by the close mat of vegetative growth it produced, because, regardless of the fact that there was more dry matter produced on the land cropped to corn and cowpeas as compared to corn alone, up to August 2d, less water was used under the former treatment. This resulted in more water being left available to the corn plant during the mid-summer semi-drought period when the crop was in greatest need of it. (See, water used August $2 d$ to November 12th, 1912, under respective treatments.)

TABIE XI

YIBID OF CORN IN BUSHELS PER ACRE UNDER VARIOUS TREATMENTS.

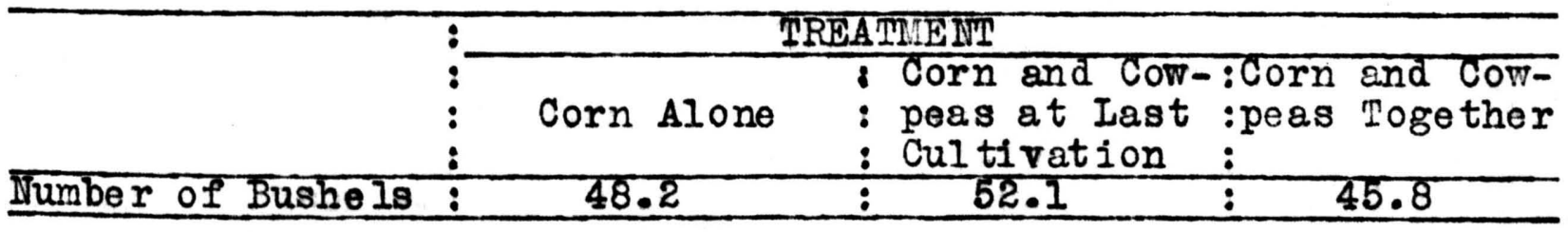

From Table XI it is seen that the yield of corn when corrected to stand is only slightly different under the treatments used. A check was not man on soil variation in this field, but aside from such probable source of error, it would be safe to say that this year, on Station plots, a companion crop of cowpas in corn did not have a consistant effect of reducing the quantity and quality of the corn jield. Furthermore, a study of the nitrate and moisture content of the plots made at periods throughout the season, as before 

described, show that any bad effect the compea may have in reducing corn ylelds must find its origin in some other phenomena than a removal of either moisture or nitrates.

\section{PART II}

TO DETERMINE THE CAUSE OF SOII FRIABIIITY

UNDER COWPEAS

PLAII OF PLOTS

\begin{tabular}{|c|c|c|c|}
\hline $\begin{array}{c}\text { PIOT I } \\
\text { D }\end{array}$ & $\begin{array}{l}\text { PLOT II } \\
\end{array}$ & $:$ PIOT III & $\begin{array}{cccc} & \text { PIOT IV } & \text { PIOT V } \\
& G & \text { H } & \text { H } \\
\end{array}$ \\
\hline $\begin{array}{l}\text { Unplowed, no } \\
\text { kept clean }\end{array}$ & $\begin{array}{l}\text { orop, : Unplowed } \\
\text { :Cowpeas } \\
:\end{array}$ & $\begin{array}{l}\text { Plowed } \\
\text { : Cowpeas }\end{array}$ & $\begin{array}{l}\text { :Plowed, no:Plowed, no } \\
\text { :Cowpeas, } \\
\text { : Cowpeas, kept } \\
\text { : Clean }\end{array}$ \\
\hline
\end{tabular}

IOCATION OF PLOTS

F18. I.

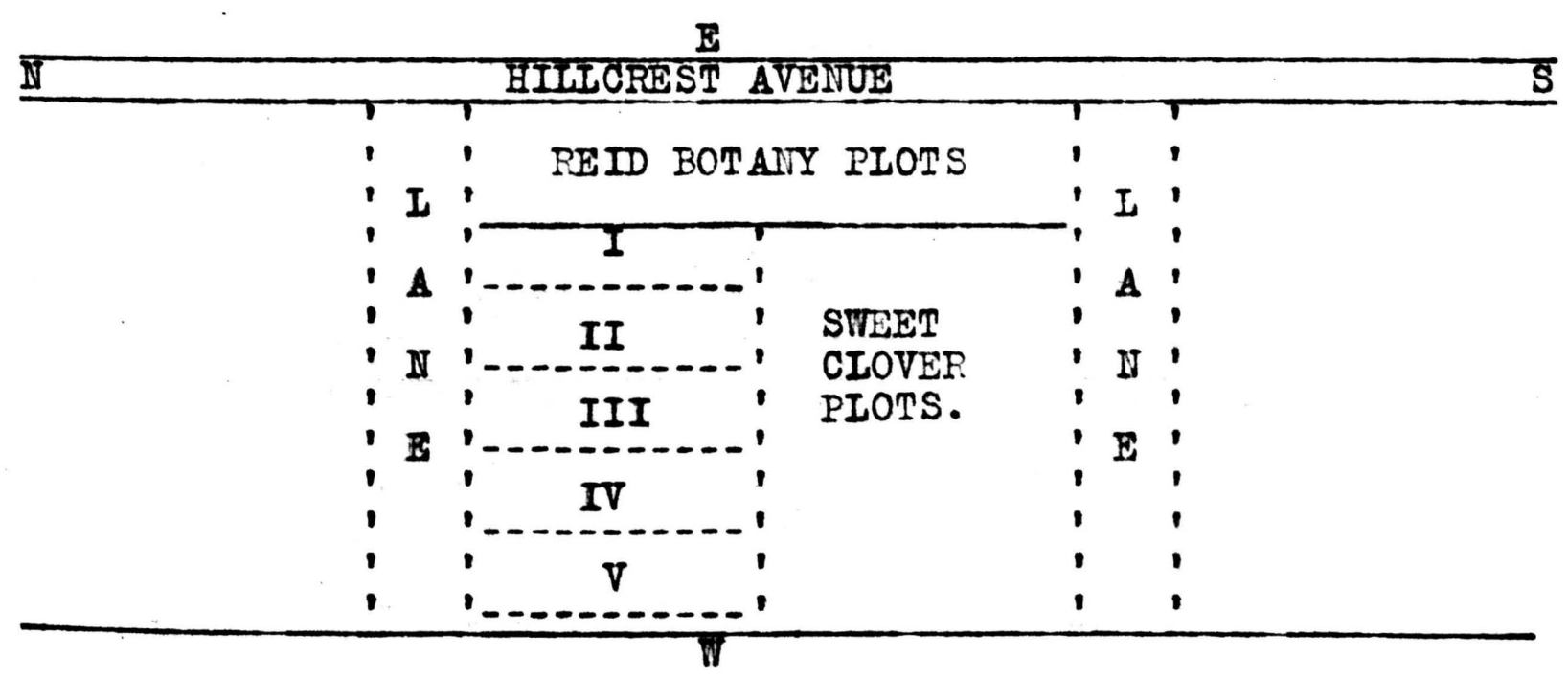

The plots were la1d out on May 31st, 1912. Plots III, IV, and V vere carefully spaded at this time. Plots I and II were scraped with a hoe to remove trash and weeds, but no further treatment was given. A week later, June 1lth, 1912, plots II and III were drilled to Black compeas. 

An ordinary wheat drill was used, putting the peas in eight inches apart at the rate of one and one-half bushels per acre. The arill was operated by pulling it at the end of a long rope so that the horses were not permitted to walk over the plots. On Saturday, June 9th, 1912, after planting, all plots were gently scraped with a hoe to give them an equal start.

The main point at issue was a study of the soil compactness and nitrate content of plots to the various treatments at the beginning and end of the growing season. An artificial shade was erected on Plot IV at a time when the cowpeas on Plots II and III were matting over the soil. The shade device was a frame made of $2^{\prime \prime}-4 "$. Iumber supported on legs made of the same material (See Fig. II). Over this, some galvanized screen was tightly stretched to serve as a support for a thin, black plece of cheese cloth, which was found efficient in shading the soll from the direct rays of the sun and only very slightly impeding the beating of the rain.

\section{F18. II}

Showing the Construction of the Shade Device.

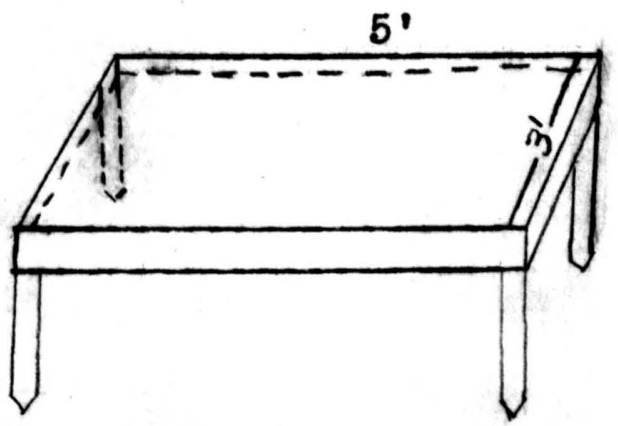



Compactness tests we re made by counting the number of times a weighted ram had to be dropped from a specified height in order that a conical pin be ariven a given distance in the soil. (See Fig. III.) Fifteen determinations of this character were made in each plot and the average of these taken as representative.

The first observations were made on June 19th, 1912, The soll was very friable at this time. Several showers had fallen since planting time and consequently the plots were in excellent tilth.

A definite system was followed in looating places for compactness determinations, just as described under methods of taking samples for analysis. This eliminated any chance of auplicating a measurement of a given spot, at later times. Tests were made at least eighteen inches apart to further avoid any influence due to overlapping. In manipulating the mechanical device (See FIg. III), auger plate "F" was placed squarely on the ground and $p$ in "D" was set in the aperature. Sheat "F" was then slipped over "D" and ram "G" pressed on pin until it was ariven into the soil sufficiently deep so that mark "B" on ram was even with the surface of sheath "H". The ram was raised each time to "A" and then dropped freely by Its own weight ( 7445 grams). This operation was repeated, recording each drop, until point "C" on ram was even with upper surface of sheath at "H". Thus the pin was ariven a distance of four and one-half inches in the ground each time a test was made. The number of drops necessary to produce this effect was the measure of the relative compactness of so1l in respective plots. 


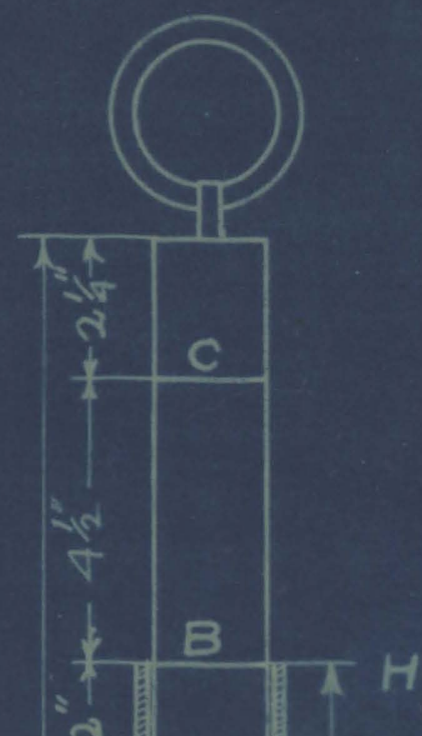

Fie III

ShOWINGCOMPACTNESS

DEVICE READY FOR ACTION

G

2

a

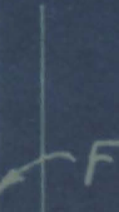

E 



\section{TABLE I}

RELATIVE COMPACTNESS OF SOII AT THE BEGINIING

OF THE EXPERIZENT

June 19, 1912.

\begin{tabular}{|c|c|c|c|c|c|c|}
\hline Trial & $\begin{array}{l}\text { :Unplowed } \\
\text { :Clean } \\
:\end{array}$ & $\begin{array}{l}\text { :Unplowed } \\
\text { :Corpeas } \\
:\end{array}$ & $:$ & $\begin{array}{l}\text { Plowed } \\
\text { Cowpeas }\end{array}$ & $\begin{array}{l}\text { :Plowed } \\
\text { :tifi cial } \\
\text { : Shade }\end{array}$ & $\begin{array}{l}\text { Ar- } \\
1 \text { :Plowed } \\
: \text { Clean } \\
:\end{array}$ \\
\hline $\bar{I}$ & $I 7$ & $:$ & $\div$ & 3 & $: \quad 2$ & $: 3$ \\
\hline$\overline{2}$ & 22 & $\div$ & $\div$ & 6 & $\div$ & $: 3$ \\
\hline 3 & 18 & $\div$ & $\div$ & 3 & $:$ & $: 4$ \\
\hline 4 & 12 & $:$ & $\div$ & 3 & 4 & $: 3$ \\
\hline 5 & 13 & 14 & $:$ & 3 & 4 & $: 3$ \\
\hline$\frac{6}{6}$ & 12 & 12 & $\div$ & 3 & $:$ & $: 2$ \\
\hline 7 & 12 & 13 & $\div$ & 4 & 3 & $: 4$ \\
\hline 8 & 10 & 11 & : & 6 & 3 & $: 2$ \\
\hline 9 & 13 & 9 & $\div$ & 3 & 4 & $: 2$ \\
\hline 10 & 11 & 13 & $\div$ & 4 & 3 & $: 3$ \\
\hline 11 & 10 & 15 & : & 3 & 4 & $: 2$ \\
\hline 12 & 12 & 10 & $\div$ & 3 & 3 & $: 3$ \\
\hline 13 & 16 & 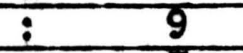 & $\overline{:}$ & 6 & 5 & $\because 1$ \\
\hline 14. & 11 & 5 & : & 3 & 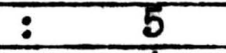 & $: 2$ \\
\hline 15 & 12 & $:$ & $\div$ & 5 & 4 & $: 2$ \\
\hline Average & 13.3 & 10.5 & : & 3.6 & 3.4 & 3.6 \\
\hline
\end{tabular}

The fluctuation between readings as seen in Table I cannot be accounted for other than that it represents the normal variation of soil friability over large areas. Increasing the number of readings did not materially alter the average secured. So the authentic average compactness of the plowed and unplowed plots stand in the ratio of one to four at this time. Moisture determinations were made on the following day with no rain intervening and were as follows:

\section{TABIE IIA}

PER CEIT OF MOISTURE IN SOII AT TIME COMPACTNESS WAS IEASURED

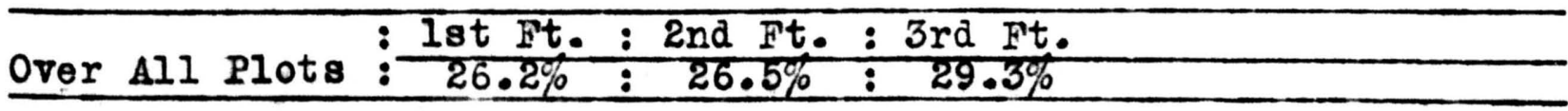

On June 24th, 1912, all plots were lightly cultivated with a hoe in order to remove the weeds which had begun to 

appear. At this time the peas were doing very well and stood about four inches high. Samples for nitrate analysis showed the soil to contain at the beginning of the experiment the amounts tabulated in Table IIB

\section{TABIE IIB}

PARTS PER WIIUION OF NO3 IN THE SOIL OF AII PLOTS JUIE 24 th, 1912 .

\begin{tabular}{|c|c|c|c|c|c|c|}
\hline No. of Core & $:$ & lst Ft. & $:$ & 2nd $\bar{E}$. & $\div$ & 3ra Ft. \\
\hline $13 \mathrm{C}$ & $:$ & 6.14 & $:$ & 3.21 & $:$ & 5.11 \\
\hline $14 \mathrm{C}$ & $\div$ & 6.93 & $:$ & 6.13 & $:$ & 2.37 \\
\hline $15 \mathrm{C}$ & $:$ & 6.46 & $:$ & 3.51 & $:$ & 3.27 \\
\hline $16 \mathrm{C}$ & $:$ & 7.26 & $:$ & 3.20 & $:$ & 3.66 \\
\hline $17 \mathrm{C}$ & $:$ & 12.25 & $:$ & 3.76 & $:$ & 3.05 \\
\hline $18 \mathrm{C}$ & $:$ & 3.93 & $:$ & 3.25 & $\div$ & 4.78 \\
\hline $19 \mathrm{C}$ & $:$ & 9.15 & $\div$ & 4.05 & $\div$ & 2.09 \\
\hline $20 \mathrm{c}$ & $:$ & 5.86 & $:$ & 3.69 & $:$ & 4.35 \\
\hline $21 C$ & $:$ & 7.43 & $\div$ & 3.31 & $:$ & 2.26 \\
\hline $22 C$ & $:$ & 9.30 & $\because$ & 3.76 & $:$ & 2.58 \\
\hline Average & $:$ & 7.46 & $:$ & 3.79 & $:$ & 3.35 \\
\hline Composite & $:$ & 8.06 & $:$ & 3.81 & $\div$ & 3.56 \\
\hline Final & $:$ & 7.76 & $:$ & 3.80 & $:$ & 3.45 \\
\hline
\end{tabular}

As might naturaliy be expected there is most nitric nitrogen in the surface foot with a gradual decrease downward. The analysis of individual cores also substantiates the conclusion derived from preliminary tests, namely, that a thoroughIy mixed composite is an authentic measure of the actual nitric nitrogen in the $\mathbf{s}$ oll.

About a month after planting to cowpeas the photographs labeled Flgures III and IV respectively were taken. They show the general plan of the experiment and the thriftinoss of the peas at the early date of July 17th, 1912. 




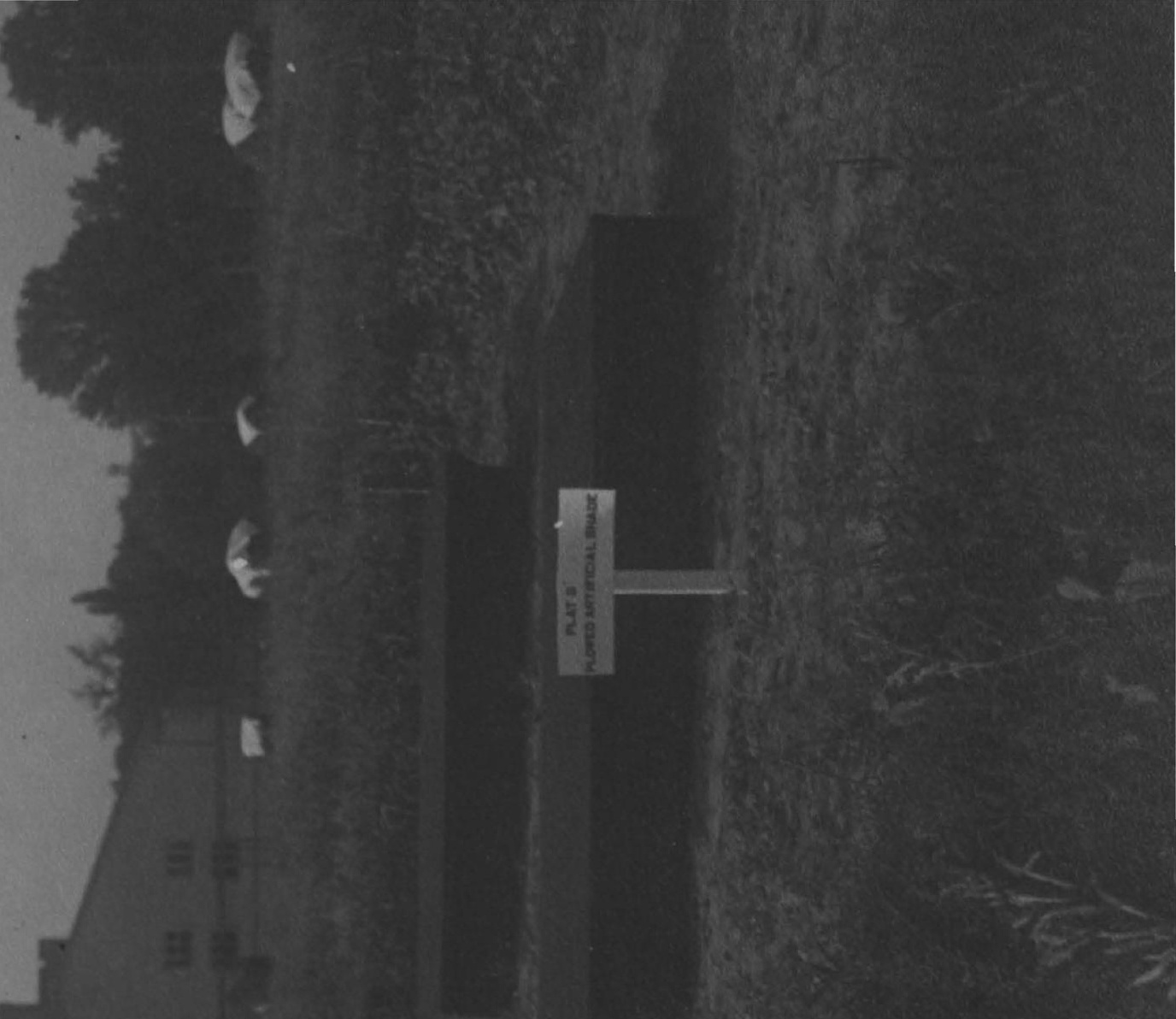



Picture on preceding page, F1g. III, looking from right to left, shows unplowed plot kept clean, unplowed plot to peas and plowed plot to peas, respectively.

Ploture on preceding page, Fig. IV, looking from right to left shows plowed plot kept clean and artificially shaded and plowed plot kept clean and not shaded.

Observations take n August 21st, 1912, showed the cowpeas on the plowed plot to be only a little heavier than those on the adjacent unplowed plot. Bloseoms had already begun to appear, and runners measured from one to two feet in length. Some crab grass had sprung up but only few other woeds were noticed. The shades were in very good condition all through to date and the soll beneath seemed normal save that it was covered w1th a growth of green algae. This was also true of the soil under peas but to a less marked extent. Great care was given to details such as freeing from weeds, renewing the covering of the shade device, etc., throughout the season. Just before frost, compactness tests were again made on all plots after removing the compea vines. The vines were cut with a scythe and the strip walked on by the operator was eliminated from the test areas. Data securod for October 15th, 1912, is represented in Table III for compectness and Table IV for molsture left in the soil. 



\section{TABIE III}

COIPACTIESS OF PLOTS AS IREASURED

ON OCTOBER 15TH, 1912 .

\begin{tabular}{|c|c|c|c|c|c|c|c|c|}
\hline \multicolumn{9}{|c|}{ TREATMENT } \\
\hline $\bar{D}$ & $:$ & $\frac{1}{\text { Unn }}$ & 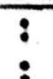 & $\bar{p}$ & $!$ & $\begin{array}{c}G \\
\text { Ploped }\end{array}$ & 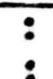 & $\begin{array}{c}\text { H } \\
\text { Plowed }\end{array}$ \\
\hline $\begin{array}{l}\text { Unplowed } \\
\text { Clean }\end{array}$ & $\vdots$ & $\begin{array}{l}\text { Unplowed } \\
\text { Cowpeas }\end{array}$ & $\vdots$ & $\begin{array}{l}\text { Plowed } \\
\text { Cowpe as }\end{array}$ & $\vdots$ & $\begin{array}{l}\text { Plowe d } \\
\text { Shade }\end{array}$ & $:$ & $\begin{array}{l}\text { Plowed } \\
\text { clean }\end{array}$ \\
\hline 20 & $\div$ & 18 & $\div$ & 4 & $\div$ & 6 & $\div$ & 5 \\
\hline 19 & 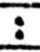 & 12 & $\div$ & 5 & $!$ & 6 & $:$ & 6 \\
\hline 17 & $:$ & 19 & $:$ & 3 & $:$ & 5 & $:$ & 7 \\
\hline 18 & $\bar{i}$ & II & $\div$ & 3 & 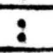 & 6 & $\vdots$ & 6 \\
\hline 20 & $\div$ & 14 & 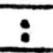 & 5 & $\div$ & 6 & : & 6 \\
\hline 24 & $i$ & 17 & 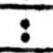 & 3 & 5 & 6 & $:$ & 5 \\
\hline 20 & $:$ & 14 & $\div$ & 4 & $:$ & 6 & $:$ & 5 \\
\hline 20 & 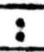 & 15 & $\bar{i}$ & 3 & 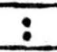 & 5 & $:$ & 5 \\
\hline 19 & : & 17 & 5 & 3 & $i$ & 5 & $:$ & 7 \\
\hline$\overline{22}$ & $:$ & 17 & $:$ & 5 & $:$ & 5 & $:$ & 6 \\
\hline 16 & $\bar{\vdots}$ & 15 & 5 & 4 & $:$ & 7 & $:$ & 8 \\
\hline 16 & $:$ & 15 & $i$ & 5 & $:$ & 6 & $:$ & 5 \\
\hline 23 & $:$ & 15 & $:$ & 3 & $i$ & 6 & $:$ & 5 \\
\hline 19 & $:$ & 18 & $i$ & 4 & $:$ & 7 & $:$ & 6 \\
\hline 19 & $i$ & 18 & $:$ & 5 & $:$ & 7 & $:$ & 5 \\
\hline 20 & $\div$ & 16 & $:$ & 3 & $:$ & 6 & $\div$ & 7 \\
\hline 21 & 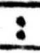 & 16 & 5 & 4 & $!$ & 6 & : & 7 \\
\hline 18 & $:$ & 15 & $\div$ & 5 & $:$ & 6 & $\div$ & 8 \\
\hline 19 & : & 11 & $:$ & 5 & 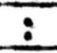 & 5 & $:$ & 6 \\
\hline & & & & RAGE & & & & \\
\hline 19.4 & $\theta^{\circ}$ & 15.4 & $\cdot$ & 4.0 & $\cdot$ & 5.9 & : & 6.0 \\
\hline
\end{tabular}

The relative compactness as shown in Table III was duplicated, using a modification of the method which originated with E. Wollney, namely, the apparent specific gravity of the soil in each plot was determined. A metallic brass tube 7.8 centimeters in diameter was driven to a depth of 23.2 contimeters in the soil. The tube was then dug out and the contact below broken. Duplicate cores of soil from each plot were thus secured, taken to the laboratory, dried and weighed. The dry weight of the soil divided by the volume of the cylinder $(1,465 \mathrm{cc})$, is the apparent specific gravity and should be an index to friability. See data in Table IV below. Wollney compared porosity of cores similarly taken by measuring the relative amounts of water needed to fill the pore space, but the prineiple is the same in both cases. 

TABIE IV

APPAREIT SPECIFIC GRAVITY OF SOII

UIDER VARIOUS TREATIENTS

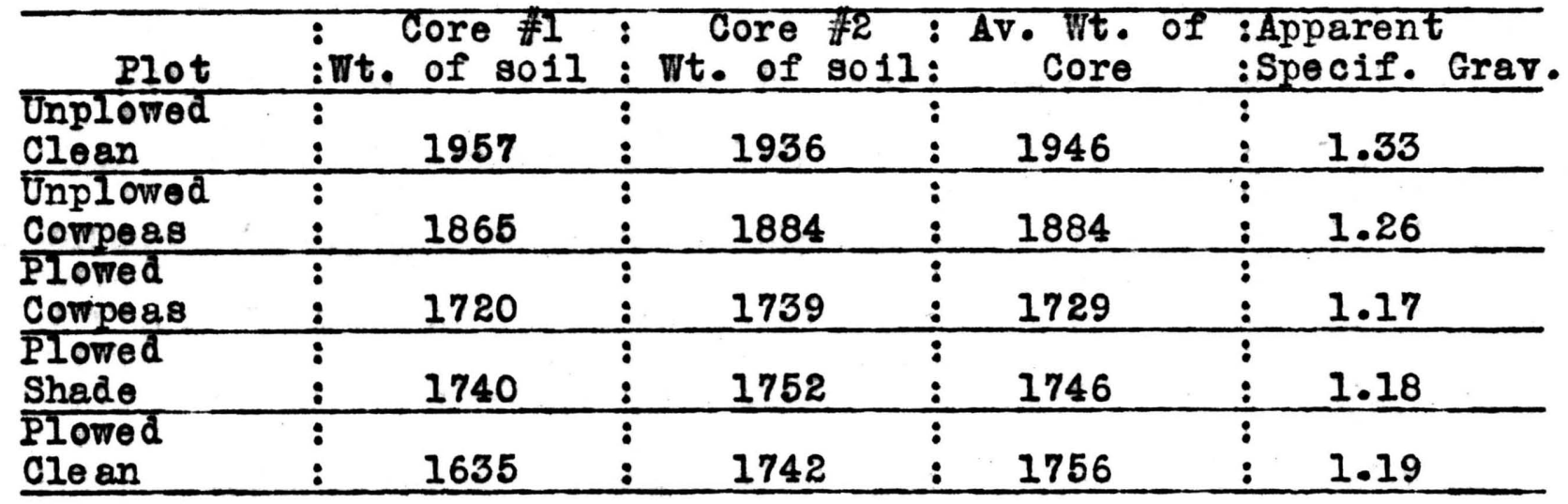

Checking the results found by the Wollney mothod with those shown in Table. III the same ratio is found to hold in overy case. This gives strong assurance that the use of the compactness device, by means of which the results of Table III were obtained, is an acourate method of measuring soil friability and, in that it is easily and rapidiy made, a very desirable one.

\section{TABIE V}

PER CENT OF MOISTURE IN PLOTS

On October 15th, 1912

\begin{tabular}{|c|c|c|c|c|c|c|c|c|}
\hline reatment & $:$ & Ist Ft. & 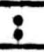 & 2nd $\mathrm{st}_{\text {t. }}$ & 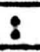 & 3rd Ft. & $\dot{:}$ & 4th Ft. \\
\hline $\begin{array}{l}\text { Unplowed } \\
\text { clean }\end{array}$ & $\vdots$ & $17.9 \%$ & $\vdots$ & $29.4 \%$ & $:$ & $24.2 \%$ & : & $22.5 \%$ \\
\hline $\begin{array}{l}\text { Unplowed } \\
\text { Cowpeas }\end{array}$ & $\div$ & $25.2 \%$ & $\vdots$ & $28.1 \%$ & 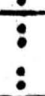 & $17.9 \%$ & $\vdots$ & Now \\
\hline $\begin{array}{l}\text { Plowed } \\
\text { Cowpeas }\end{array}$ & $\vdots$ & $21.7 \%$ & - & $\%$ & $\circ$ & $16.5 \%$ & $\vdots$ & $18.8 \%$ \\
\hline $\begin{array}{l}\text { Plowed } \\
\text { Shade }\end{array}$ & $\vdots$ & $19.2 \%$ & - & $29.0 \%$ & $\vdots$ & $25.9 \%$ & $\vdots$ & $26.9 \%$ \\
\hline $\begin{array}{l}\text { Plowed } \\
\text { clean }\end{array}$ & $\vdots$ & $11.2 \%$ & : & $28.3 \%$ & $\dot{0}$ & $27.9 \%$ & 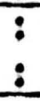 & $25.3 \%$ \\
\hline
\end{tabular}



A study of the molsture in the soil at the close of the experiment as shown by the above table, reveals, as would be expected, that the plots to corpeas leave less moisture in the soil than do the plots uncropped and kept clean. strange to say, however, this use of water is from below the second foot. Under cowpeas the surface foot as well as the second foot below contains as much water as is found in the unoropped plots for the same depth. It would seem, then, that the cowpea plant is a comparatively deep feeder and the shade of its leaves serves as a blanket to prevent evaporation. This conclusion is again borme out by a study of the molsture content of the soil under the artiff cial shade. Now, since only the moisture in the first foot could possibly affect the degree of compactness, or looseness at any one time, a direct comparison of the data shown (Table III) with that secured at the beginning of the experiment (Table I), can be mad, for, on Ootober 15th, the moistare in the first foot of every plot, save five(v), was within the limit of varlation where by preliminary tests effects due to water can be appreclated by our means of measurement.- Therefore, disregarding water as a factor, it is apparent that cowpeas possibly have a tendency to maintain the friability of either plowed or unplowed land. The data, also, shows that the plowed plot artificially shaded was almost as compact as the adjacent plowed plot not shaded. This may be interpreted either, that the ahade was inefficient or that the loosening of the soll is due to some other factor. From the conclusions of $\mathrm{E}$. Wollney on this point and experimental data to be presented below, it seems probable that this 

preservation of soil structure is due to increased bacterial activity resulting in the formation of humus. This was actually demonstrated by wollney.

The nitrate analysis of the plots at the close of the experiment together with bacterial count, nitrifying efficiency and ammonifying efficiency are given in Table VI below.

\section{TABLE VI}

NITRATE ANALYSIS - BACTERIAI COUNT - NITRIFYING AND

AIMONIFYING EFFICIENCY OF SOIL ON

OCTOBER 15th, 1912.

PARTS PER MIILION OF $\mathrm{NO}_{3}$ IN THE SOIL

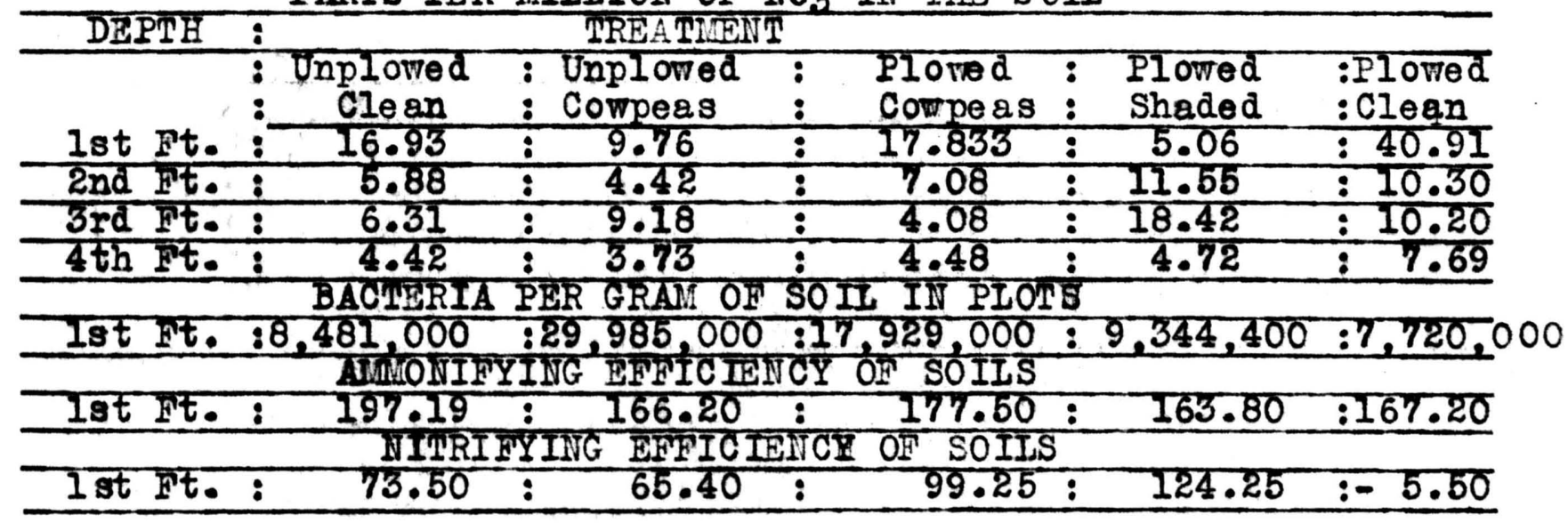

The amounts of nitric nitrogen in the soil, as shown by data of Table VI, reveals the fact that at this season of the year all plots are going into winter with more available nitrogen in the soil than they contained in the eerly spring as shown in Table IIB. It is also seen that cultivated plots either cropped or uncropped are richer in nitric nitrogen at the end of the season than are the plots not plowed. The low nitrate content of the first foot of the plot artificially 

shaded cannot be explained. Lastly, the results check with previous investigations in the fact that under even a legume treatment there exist less nitrates in the 50 il in the fall than under adjacent similarly treated fallowed plots. (See historical data.)

Although we have a wide range in the total bacterial count under the respective treatments, the only certain nonclusion we can draw is that under cowpeas we have larger numbers of bacteria than where no crop is on the land. The ammonifying and nitrifying efficiency of these soils as affected by the summer's treatment seemed to have been considerably Influenced by the varied conditions noted, but no correlations can be drawn. Thus, briefly summing up, it might be said that the maintenance of soil structure from spring to fall, by the growth of cowpeas on the land, is due partially to the shading effect of the foliage which even as the artificial shade resists the compacting effect of beating rains and baking sun. Besides this, there seems to be a marked correlation between the friability of the soil under peas and the bacterial flora present. Where present in largest numbers, they possibly bring about a greater production of active humus and so maintain the looseness of the soil. 



\section{PART III}

THE EFEECT OF CONTINUOUS CROPPING OF WHEAT AND CONPEAS ON SOIL PRODUCTIVENESS

In the problem concerning the decreasing of wheat jlelds on a plot subjected to a cropping system of continuous wheat and cowpeas for a series of twelve years as compared to the yields of the same crops on adjacent plot with a rotation of corn, oats, wheat and a legume, work was commenced with the assumption that the phenomena was possibly due to a chem1cal difference in the plots. As stated under the discussion of the plan of this experiment, both plots were in wheat in the spring of 1912 when this study began. Unfortunately, the data on the wheat yields in years previous has been lost, but it may be said that, on the plot where cowpeas were put in immedately after the grain was cut and allowed to grow until time for wheat again to be sown in the fall, the jield on the continuously cropped plot was at first greater but in late jears much less than the average of check plots for the respective years. Table I shows the jield in bushels per acre during the year 1912.

\section{PART I}

YIELD OF WHEAT PER BUSHEL ON PLOTS ROTATED

AND CONTINUOUSIY CROPPED FOR.

THE YEAR 1911-12

\begin{tabular}{lcccc} 
Treatment & : Continuousiy Cropped & : Wheat in Rotation \\
\hline Bushels per & $\vdots$ & 4.45 & $\vdots$ & 23.75 \\
Acre & $:$ & 4.45 &
\end{tabular}



Fig. I

SHOWING IOCATION OF PIOTS OII STATION FARM

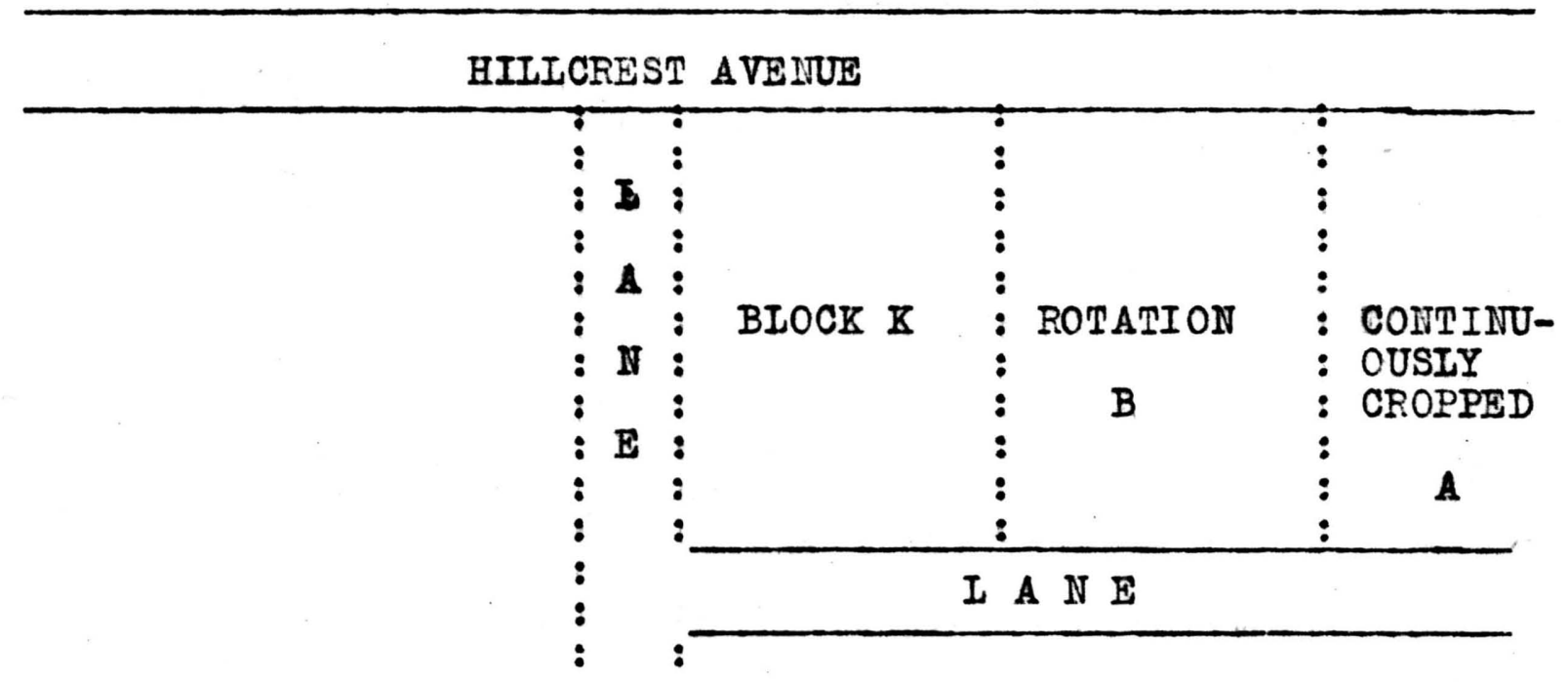

The results given in Table I seomed to show indications of soll sickness in the case of the continuously cropped plot. In that previous investigation has revealed that such conditions only exist in sour solls deficient in available plant food, an analysis was made to determine the lime requirement of both plots. Total organic matter and the closeIy correlated nitrogen supply, to gether with active humus and available phosphorus were the analyses deemed most liable to explain the phenomena of the recent low yield of the continuously cropped plot. Bacterial activity and the influence of bacteria on the available nitrogen supply, together with moisture fluctuations were studied by a series of analyses made at the following times:

(a) In early spring

(b) At whe at harvest

Results are tabula ted and di scussed below. 



\section{TABIE II}

IIIE REQUIREMENTS OF PIOTS

BY THE HOPKINS TITRATION METHOD

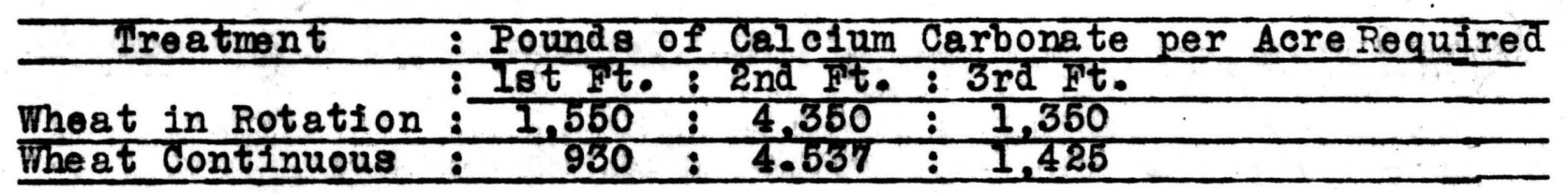

From the above, it is seen that in the first three feet of soll, in the plots considered, the continuously oropped plot requires about 325 pounds of lime less than does the plot which ha been in a good rotation. This is evidence beyond doubt that a difference of acidity cannot account for the great difference in jield as shom in Table I, page 39.

The plant food situation was then considered with special emphasis on the immediately available plant food constituents. Nitrate determinations were made just as the wheat began to appear with results as given below, together with bacterial count, nitrifying and ammonifying effioiencies.

\section{TABIE III}

\section{BACTERIAL STIDIES AND PARTS PER MIILION OF} NITRATES IN THE SOIL

June 8th, 1912 At Beginning of Experiment

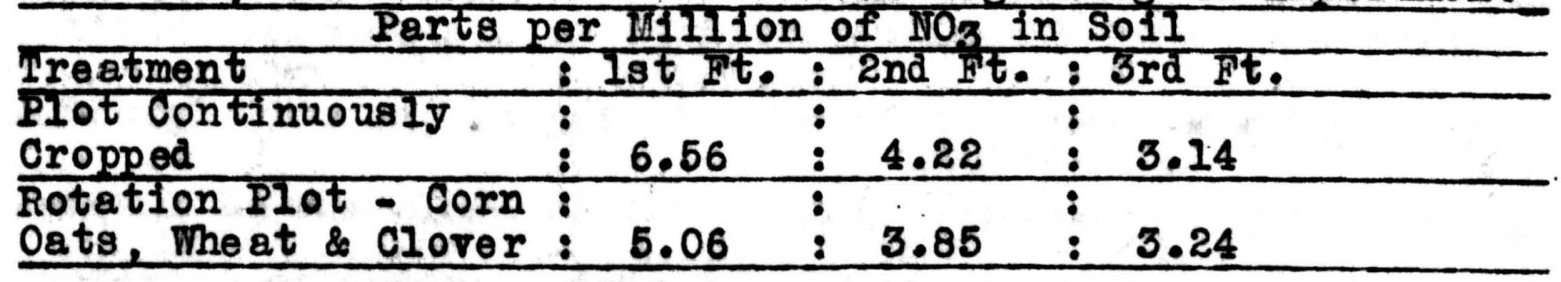





\section{BACTER IAI STUDIES}

\begin{tabular}{|c|c|c|c|}
\hline TREATMENT & :No.' In Gram & $\begin{array}{l}\text { FIRST FOOT OT } \\
\text { :Armonlfying: } \\
\text { :Efficiency }\end{array}$ & $\begin{array}{l}\text { Soll } \\
\text { Nitrifying } \\
\text { Efficiency }\end{array}$ \\
\hline $\begin{array}{l}\text { Plot Continuously } \\
\text { Cropped }\end{array}$ & $: 7,642,900$ & : 348.89 ppm: & $74.60 \mathrm{ppm}$ \\
\hline
\end{tabular}

Then the wheat was harvested on both plots and just before the ground was plowed for cowpeas on the continuously cropped plot, samples were again taken and the nitrate analysis is given in Table IV below.

\section{TABIE IV}

PARTS PER MILIION OF NO3 IN ONE GRAM OF DRY SOIL

July 16

\begin{tabular}{|c|c|c|c|}
\hline TREATMENT & $\therefore$ 1st Ft. & $:$ 2nd Ft. & $\therefore$ 3rd Ft. \\
\hline $\begin{array}{l}\text { Plot Continuousiy } \\
\text { Cropped }\end{array}$ & $: 4.59$ & 7.08 & $: 3.17$ \\
\hline $\begin{array}{l}\text { Plot Rotated - Corn } \\
\text { Oats, Wheat \& Legume }\end{array}$ & $: 6.00$ & 5.91 & $: 3.39$ \\
\hline
\end{tabular}

In pounds per acre of nitric nitrogen, this table shows that the amount present in both plots to a depth of three feot is almost the same.

Comparing Tables III and IV, it is seen that in spite of the variation in nitrifying and amonifying efficiencies as indicated by laboratory experiments, both plots contain the same amount of nitrates at the time of harvest. Although this may in part be due to the fact that the crop removal at the close of the period overshadowed the actual bacterial activity at this time, but there is no way of determining the correctness of this hypothesis. 

The similarity that exists between the amount of nitric nitrogen in the third foot (see Table IV), together wi th the fact that less than four inches of rainfall fell during the lapse of observations (see Table $v$ ) would assure beyond doubt that nothing would have been gained at this time by studying the amounts of $\mathrm{NO}_{3}$ at great depths.

\section{TABIE V}

INCHES OF RAINFALI AND DISTRIBUTION BETWEEN JUNE 8th AND JUYY 17 th

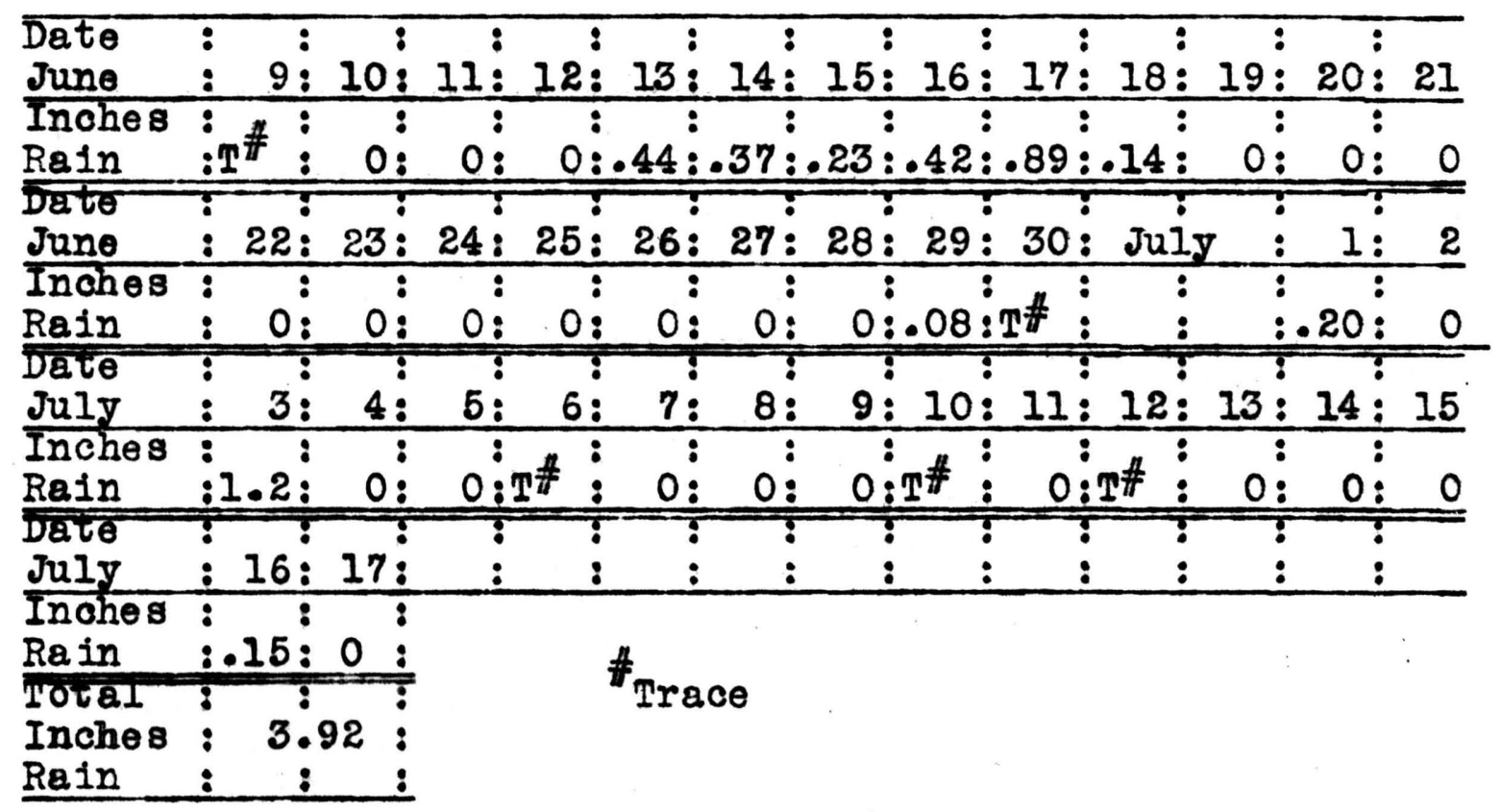

The cowpeas were permitted to grow as long as possible before harvesting and they were then out, raked off to cure, and the ground again plowed for theat. On November 12th, 1912, the whe at had grown to about three inches in height, and, as frost was expected at any time, the last set of samples for mo1sture and nitrate analysis were then taken. 



\section{TABIE VI}

\section{BACTERIAL STUDIES AND}

PARTS PER MILIION OF NO3 PER GRAM OF SOIL

ON NOVEMBER 12th, 1912

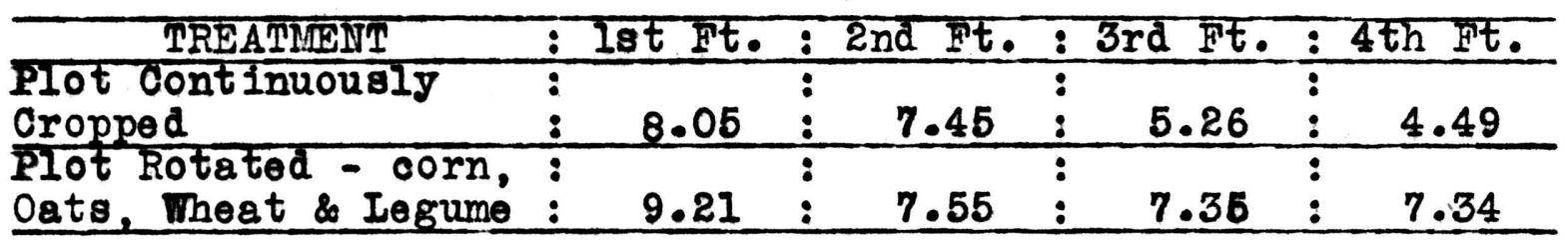

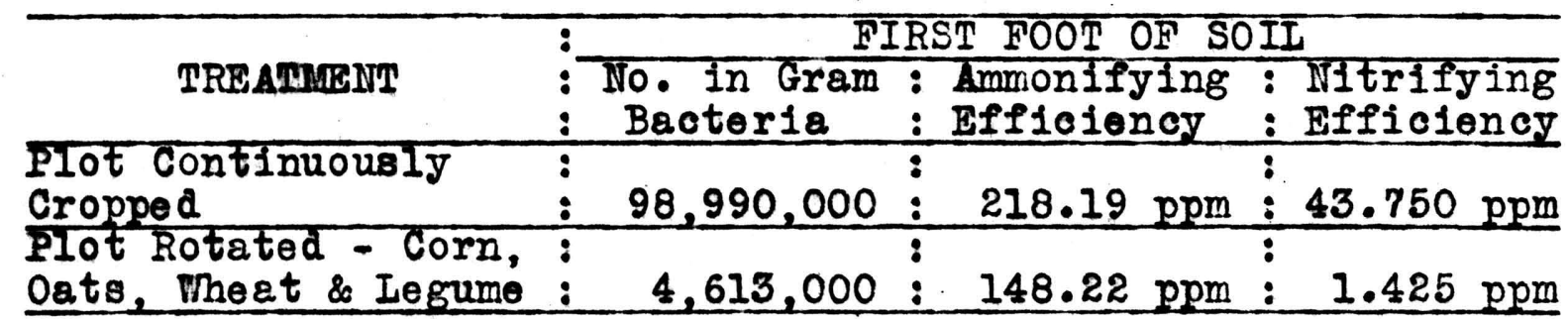

Table VI, again shows that in this treatment as in others described there exists an accumulation of nitrates in the soil as we approach the rinter months. Cowpea plants following wheat, although probably not able to secure their complete nitrogen from the air, seem to decrease but little the vinter store of nitric nitrogen. It is probable that the removal by the oatoh orop has a more favorable effect upon the production of nitrates than would be the case if the crop were not on the land and hence a balance in the soil is maintainod. Then, too, must be considered the great inorease in bacterial count under the plot seeded to peas. Thus the conclusion is necessarily drawn that thoir activity at this time was farorable to the making of plant food, other than nitrogen, available for the precoding crop. However, quoting from Mr. P. I. Gainey, to whom we are indebted for much assistance in seouring this data, we can say "That all things considered, the fertility of the rotated plot as it 

exceeds the one continuously cropped is not entirely due to bacterial activity."

Turning now to a study of water economy under the above treatment, we offer for consideration the data in Table VI.

\section{TABIE VI}

PER CEIT OF MOISTURE IN SOIL

ON JUNE 8th, 1912

At Beginning of Experiment

Plot Continuousiy Cropped

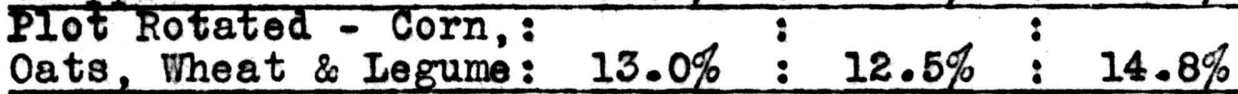

The above data shows that the plot in a rotation contains at the time observed considerably less water in the first three feet of soll than does the continuously cropped. This is probably due to the removal of water by the larger growth and better stand of wheat on the former plot or to a varied moisture content as the plots came out of winter. Considering, now, what the conditions are at harvest time a month and a half later see Table VII below.

\section{TABLE VII}

PER CENT OF MOISTURE IN THE SOIL

$$
\text { July } 17 \text { th, } 1912
$$

\section{At Harvest}

\begin{tabular}{l} 
TREATIENT $:$ Ist Ft. : 2nd Ft. : 3rd Ft. \\
\hline Plot Continuously : \\
Cropped
\end{tabular}



It is seen that the amount of moisture remaining in the soil at this time is reversed, being somewhat greater now in the rotated plot which produced the biggest yield of grein. This is accounted for by the fact that on the continuously cropped plot there was a rank growth of weeds which sapped the moisture to an even greater extent than did the good stand of grain.

TABIE VIII

PER CENT OF MOISTURE IN THE SOIL

NOVEMBER 12th, 1912

Iate Fall

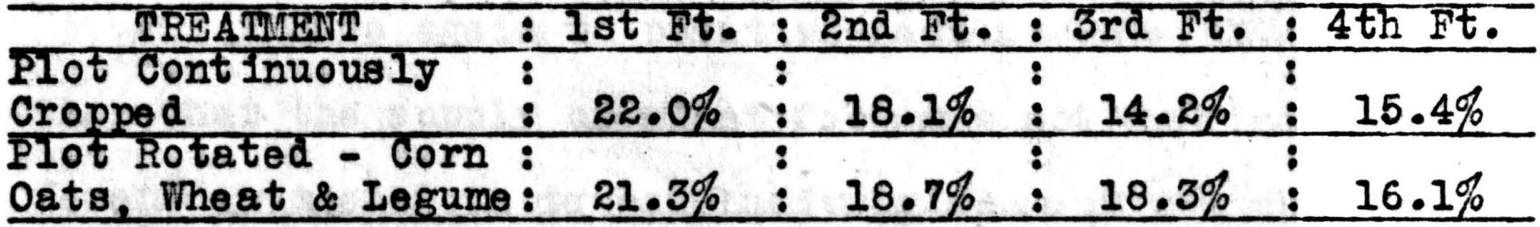

From Table VIII, it is apparent that having a catch orop during this particular season and on this soll after wheat, is no more exhaustive of so il moisture than allowing the land to lie idle, as was the case in the rotation plot.

Find ing that, from a bacteriological, acidity, and water supply standpoint, it was impossible to explain the difference in productiveness of these two plots, a comparison of the plant food supply was made. Unfortunately no analysis of the plots at the beginning of the experiment could be secured but the soil was sufficiently uniform to warrant like conditions at the outset. The soil is a silt loam and grades to clay below so that the potash factor is undoubtedly of no great import. Thus an analysis to determine the re- 

moval of this element was not deemed necessary and only total loss on ignition (organ1c matter), humus (active), total n1trogen and available phosphorus (see Table IX below) was studied.

TABIE IX

TOTAL AND AVIIIABIE PIANT FOOD IN SOIL

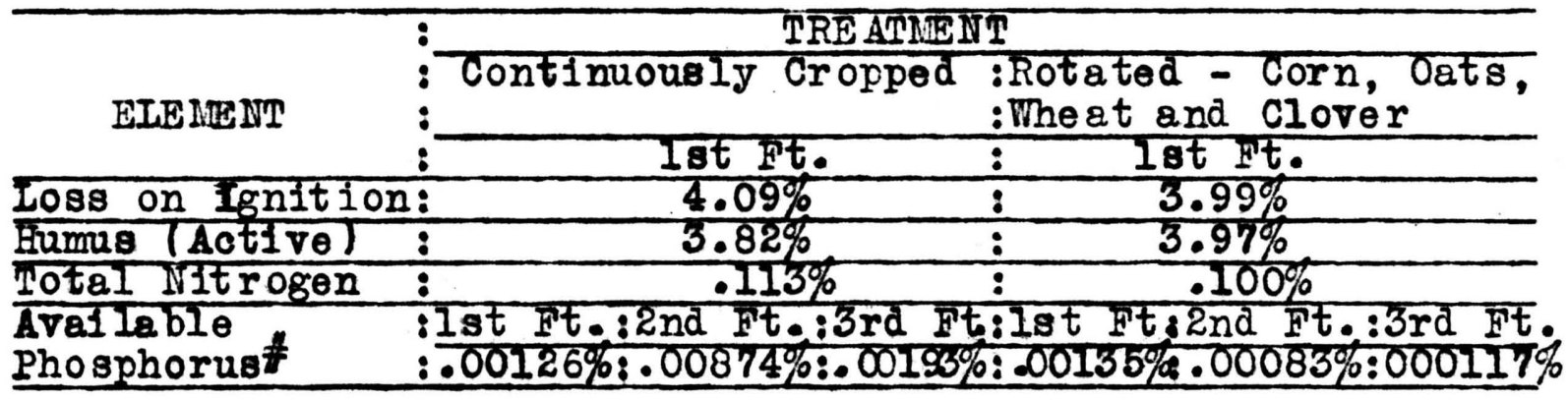

Here again no positive results were obtained other than that the supply of plant food was not sufficiently different in the plots to conclusively account fot the infertility of the continuously oropped plot. The only other alternative that presented itself was a probable toxic body in the continuously oropped plot that may have accumulated from the exoreta of the wheat or corpea plants or by reason of the soil management practised.

To investigate this proposition, soil from the continuously cropped plot was secured to a depth of one foot. After drying and mixing thoroughly, the soil was digested with toxic free distilled water in the proportion of 6 parts of water to 5 of soll. The preparation of the toxic free water, as well as the general technique of this part of the work, was carried on under the various precautions suggested by the 

United States Bureau of Soils in Bulletins Numbers 22, 23, 28, 36, 47, and 53. The muddy extract was filtered through the ordinary filter paper and then again through a porous Brigg's filter to remove clay and bacteria. Only extract from the poor plot has been used up to the present and the following treatment was given. Glass bottles of two hundred and fifty cubic centimeter capacity were sterilized, covered with black paper, and fitted with parrafined corks. In duplicate sets of three each, the bottles were filled with distilled water (toxic freo) plus a full nutrient ration (Tollen's) anả soil extract plus full nutrient ration (Tollen's). To one series, we planted sterilized wheat seedlings and to the other compeas. Hydrogen peroxide was used as the sterilizing agency and the seeds were treated for one hours.

A perfect stand was secured in all of the cultares as may be seen by reference to photograph of plants just as the first observations were commenced. (See page 48 a)

\section{TABIE X}

TRANSPIRATION OF WHEAT AID COWPEA SEEDIINGS

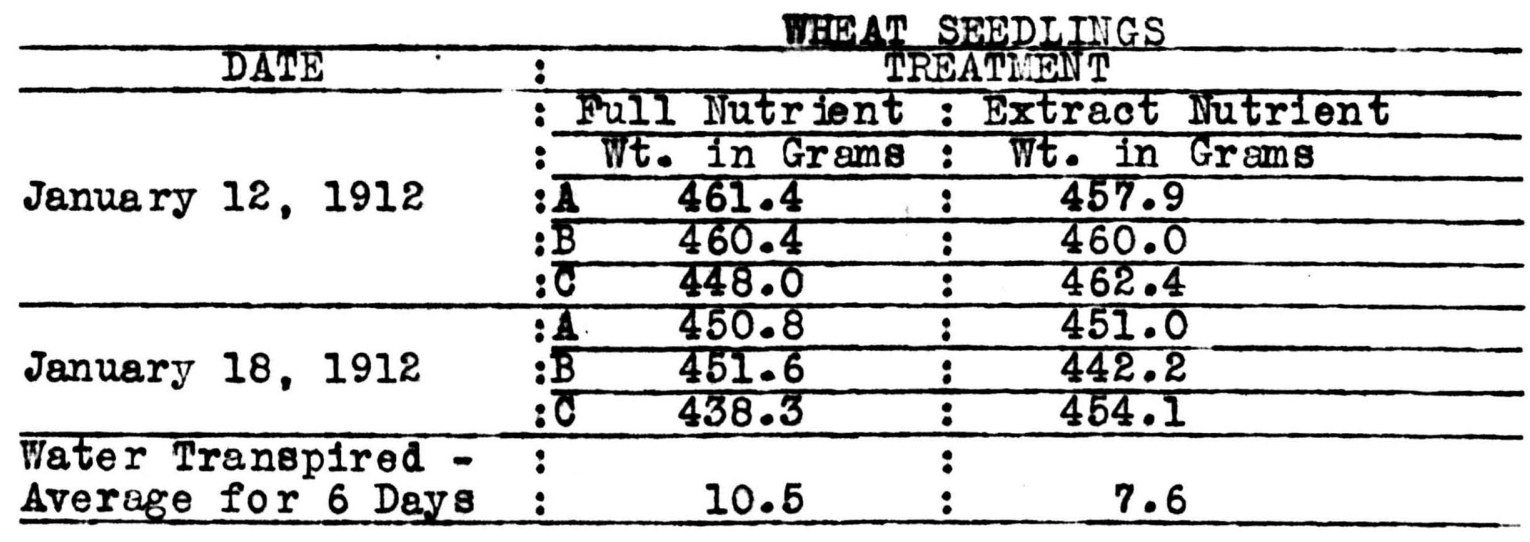





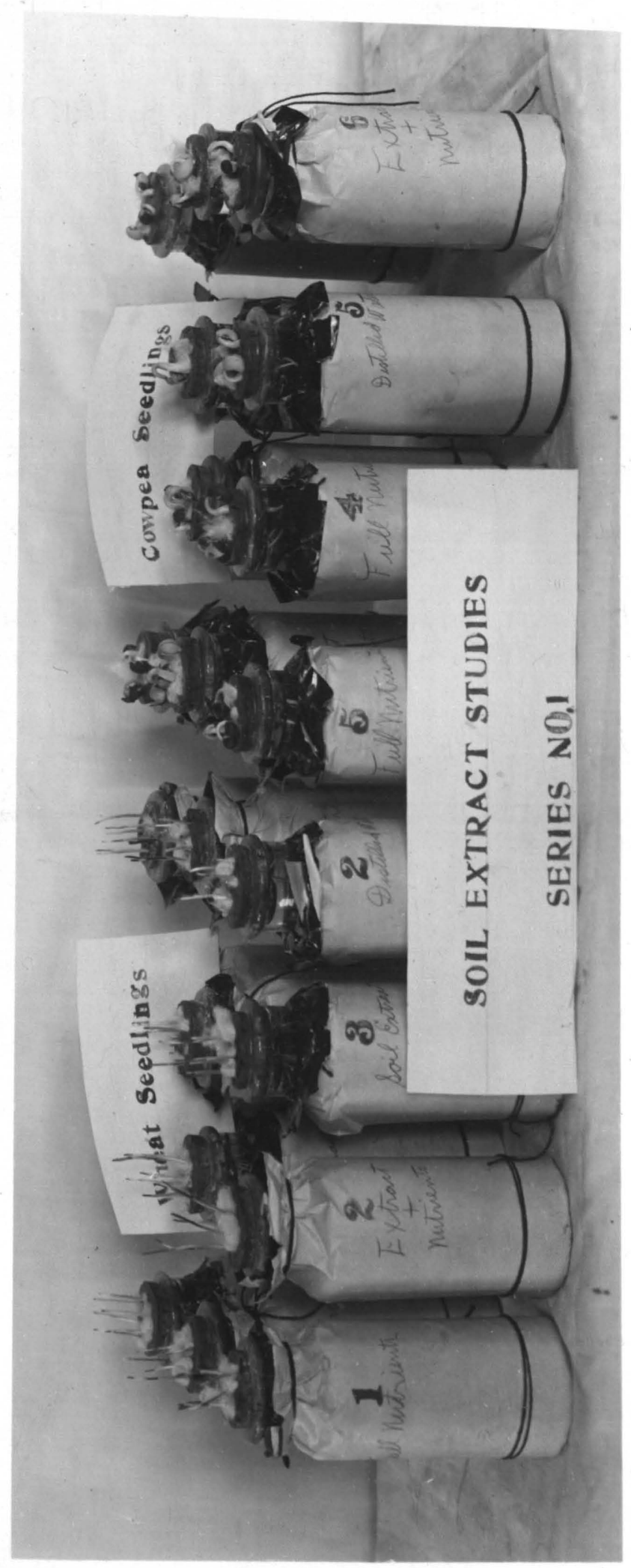



COWPEA SEEDIIIGS

\begin{tabular}{|c|c|c|}
\hline DATE & $:$ & TRE ATIE NT \\
\hline & : Full Nutrient & : Extract Nutrient \\
\hline & Wt. in Grams & $:$ Vt. in Grams \\
\hline January 12, 1912 & $D \quad 453.7$ & $: 450.4$ \\
\hline & 447.6 & 453.2 \\
\hline & 465.0 & 462.3 \\
\hline & 445.9 & 442.8 \\
\hline January 18 , & 440.0 & 441.9 \\
\hline & 456.6 & 452.7 \\
\hline Water Transpired - & $:$ & $\overline{:}$ \\
\hline Average for 6 Days & 7.9 & 8.5 \\
\hline
\end{tabular}

From the data tabulated above it can be seen that there is very little difference between the checks as to water transpired. Therefore, assuming that the ter transpired is an index to growth, it is a direct me ans of determining any deleterious effect the soil extract may have on the development of wheat, or coppeas. The series was continued twentyfour days changing solutions in all bottles in the midale of the period in order to keep plant food supply as constant as possible and provide efficient aeration.

In that the variation noted under transpiration measurements might not be proportional to the actual grorth of plants, it was arranged to harvest same at the end of the experiment. The green and dry veights are recorded in Table XI below. 

TABLE XI

GREEN AND DRY WEIGHTS OF ROOTS AND TOPS

OF PLANTS GROWN

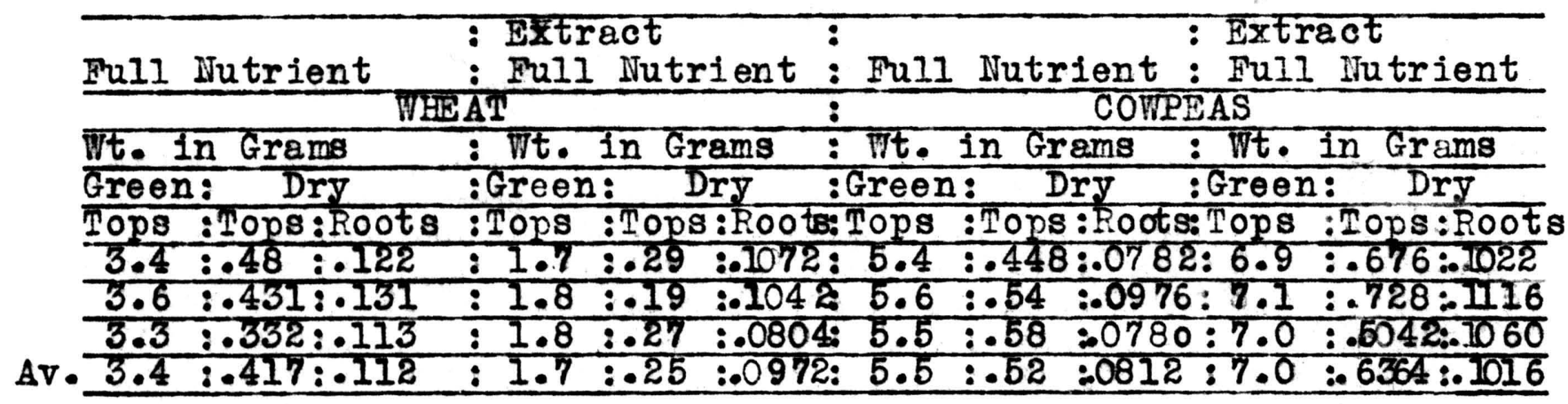

Table XI shows that for both the green and the dry weight of tops, the re is a distinct uniformity between the individuals of a given series. On the other hand, we see that the averages for various treatment are quite different. Dry weight of roots in every instance were directly proportional to the respective weight of tops even though observations made from time to time revealed the fact that the rootlets of the plants grown in soil extract were in every case more fibrous than those grown in distilled water. This was true even in the case of wheat where the soil extract had less weight of root than the full nutrient-distilled water.

\section{TABIE XII}

TOTAI AVERAGE TRAISPIRATION OF CUITURES

FOR TWENTY-FOUR DAYS

\begin{tabular}{l} 
WHEAI \\
Full Nutrient:Fxtract \& Nutrient:Full Nutrient:Extract \& Nutrient \\
Dt. In Grams: Wt. in Grams $:$ Wt. in Gms: Wt. in Grams \\
\hline $187.8: 169.6 \quad: \quad 178.6 \quad: \quad 233.1$ \\
\hline
\end{tabular}





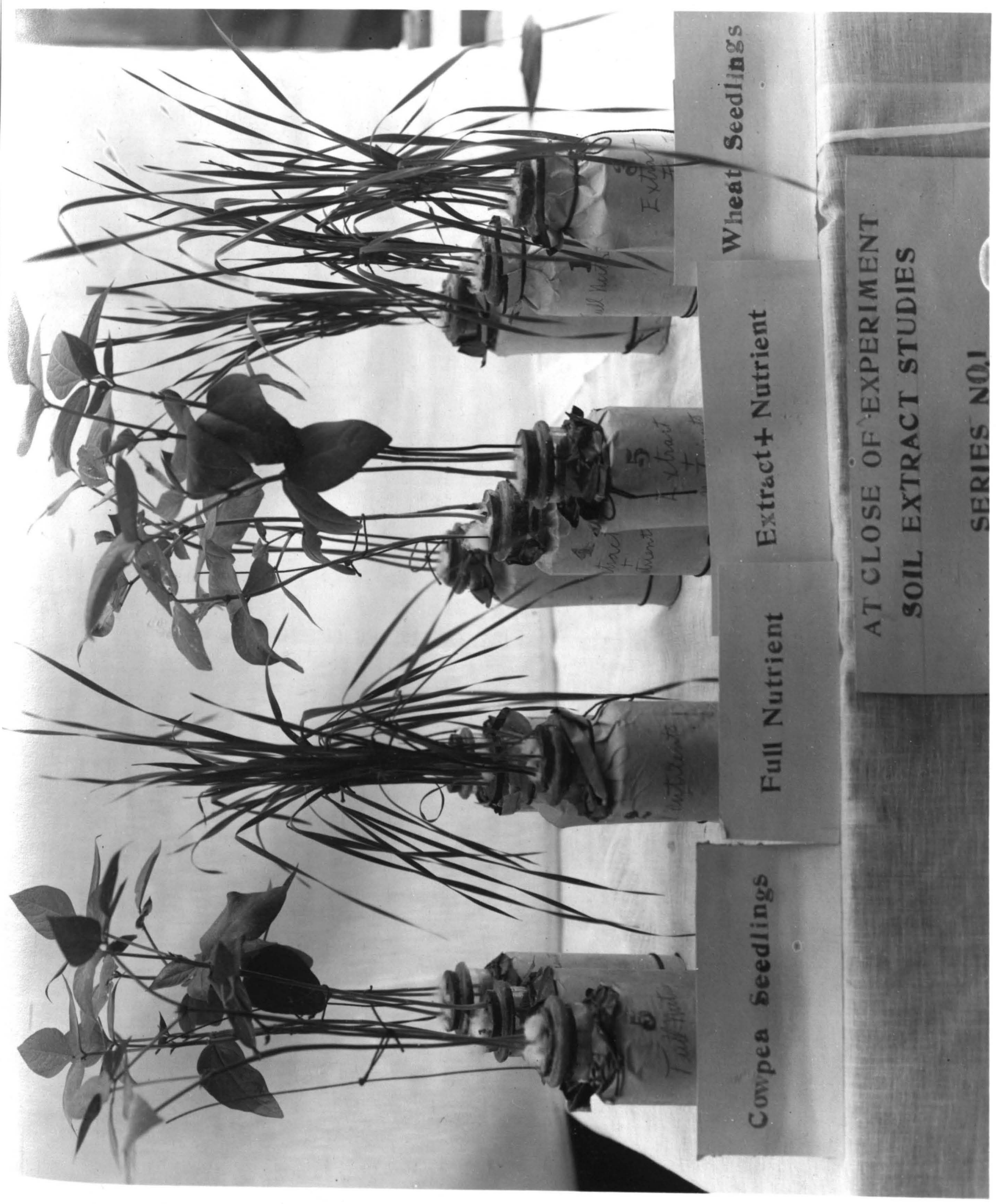





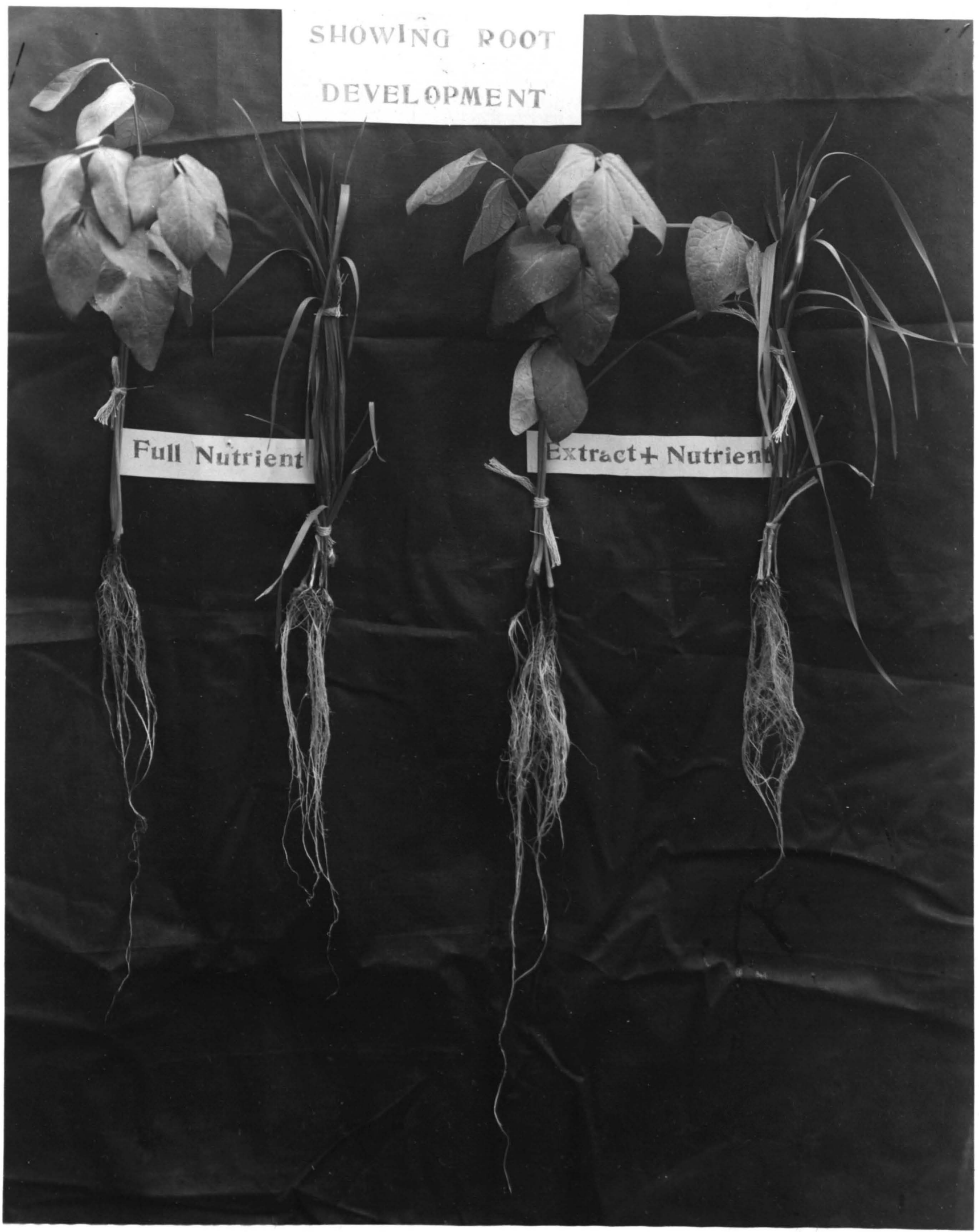



Compering results of transpiration measurements as shown in Table XII with dry weight of plants produced (see Table XI), it is seen that they check in direct proportion and we are lead to conclude from this data and physiological observations as seen by pictures on preceding pages that the extract from the soil of continually cropped plot is toxic to wheat seedlings. (See pages 51 and 52)

There is a possibility that the deleterious effect upon the wheat seedlings may have been due to the excess of mineral salts carried by the soil extract when reinforced with nutrient ration. However, in that the cowpe a plants rere not likewise affected, but as might be expected, actually stimulated by the aditional food and, further, in that the United States Bureau of Solls has proven that few soil extracts contain enough mineral food in solution to be deleterious when so treated, the above source of error may be dispensed with. It was planned to repoat the experiment, adding to the full nutrient mineral salts equivalent to the amount in the original soil extract. Then all influencing factors other than soil toxicity will be eliminated.

Hence to clear up this doubtful question another series was arranged, similar to the first in all respects, save that the distilled water cultures with the full nutrient ration vere reenforced by the extra amount of salts contained in the original soil extract. To supply this amount of salts as much soll extract as used in the "extract cultures" was evaportaed down to dryness and ignited. Thus all toxic 

organic bodies were eliminated together with the volatil radicals including $\mathbb{N O}_{3}$ which was combined with the mineral ash. The soil extract when evaporated was found to have 4.6 parts per million of $\mathrm{NO}_{3}$ and this was supplied to the ash residue by addition of nitric acid equivalent to this amount. With toxic free distilled water reenforced with full nutrients the soil extract ash residue was taken up. Therefore the available plant food in the distilled water cultures was practically identical with that of the extract and nutrient cultures.

Growth measurement was measured by transpiration as in the first run and results are reported below in Table XIII.

TABIE XIII

Transpiration of Water from Culture Bottles From Feb.27-Mar.7 No : Nutr1. \& Ash : $\mathbf{E x}$ \& \&utr1. : No :Nutri. \& Ash : Ex. \& Nutr1.

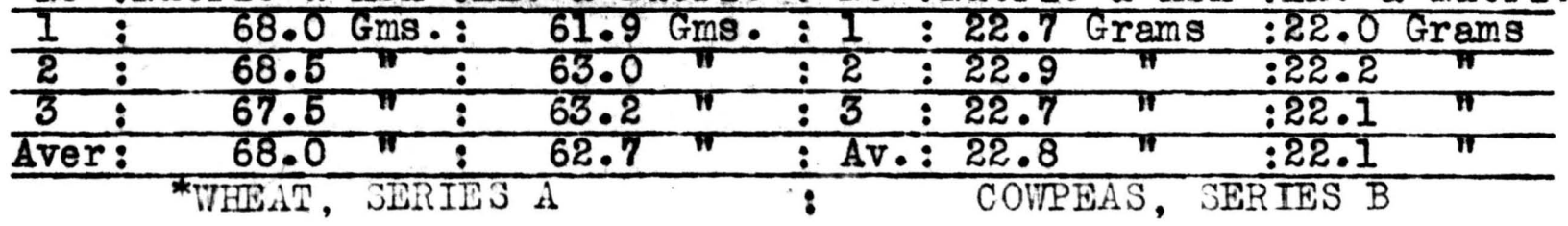

From the average transpiration data as presented above it is seen that the previous suspicion as to the toxic properties of the continuously cropped plot is substantiated. The data shows that the soil extract from the poor plot is toxic to wheat seedlings. Further, that the cowpea seedlings are not so affected and that the difference noted in the previous run was probably due to a plant food variation in the distilled water and soil extract cultures.

* See pictures on pages 55 and 56. 



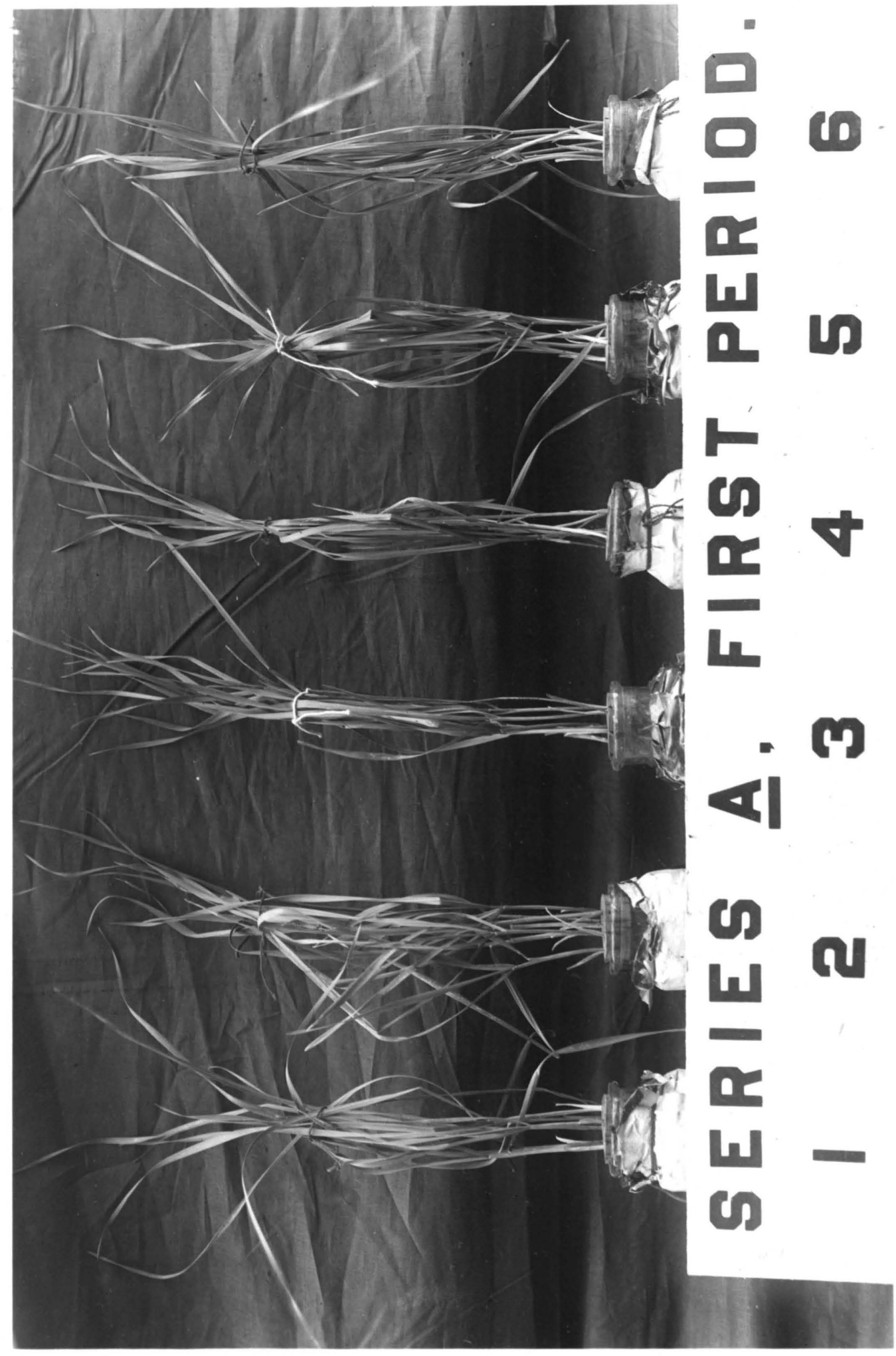





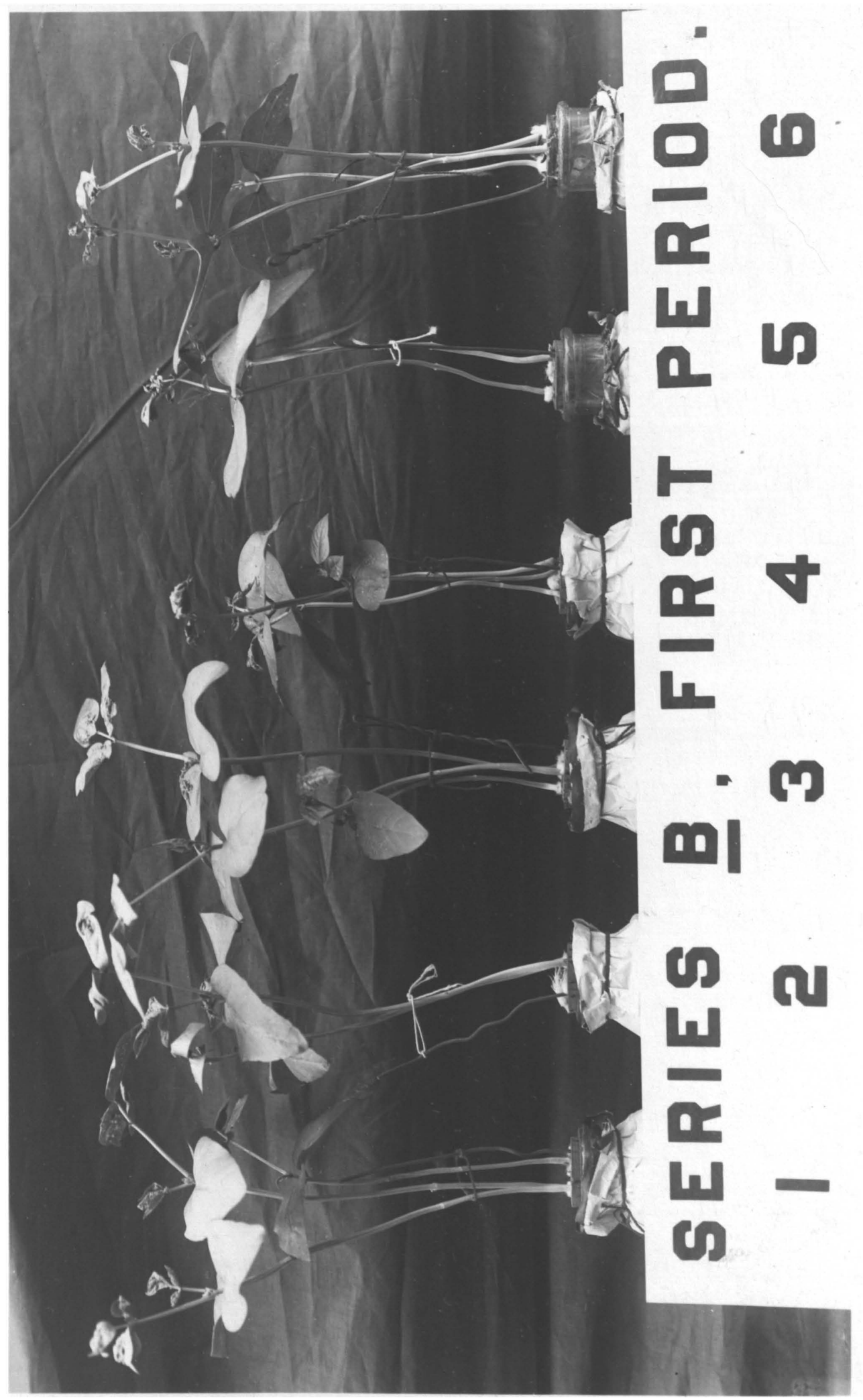



This conclusion in the case of cowpeas, however, hardly checks with actual field observations for it has been noted that the peas never make a real thrifty growth of late years even though adjacent plots produce normally. Yet, the enhanced growth noted may be due not to deleterious bodies and water but to the sall amount of available plant food left in the soil after the wheat is harvested.

Mr. P. I. Gainey, working with the soil from the same plots taken at the same time samples were secured for the preparation of soil extracts described above, prepared pot culture series. The soil was treated with .2\% toluole in one series of pots and in another it was untreated. 0ats was the crop grow and a noticeable increase of growth resulted where the soll from both plots was thus treated over that of the respective untreated checks. However, the beneficial effect of the toluole was even more marked in the case of the rotation plot soil than in the case of the continuously cropped. Investigation proved that in this treatment the toluole completely sterilized the soil so the beneficial effects are due rather to the correction of some soil condition rather than to a stimulus to bacterial activity. Why this effect should be more pronounced in the rotation soil than the other, is unexplainable save that it may be due to some characteristic of the plant gromn, or to the fact that toluole removes some deleterious factor common to both plots. Future experiments with this in mind, using other plants, will be conducted with the bope of throwing more light upon this complex problem and of the identification of the deleterious body or bodies. 



\section{CONCLUSIONS.}

\section{PART I}

1. The data seems to warrant the conclusion that a legume companion crop, such as cowpeas with corn, not only has no deleterious effects, but rather, has a simulating effect upon the quantity of $\mathrm{NO}_{3}$ produced during the groving season.

2. Cowpeas planted with corn, or at last cultivation seem to have a tendency to prevent surface evaporation, giving more water to the corn plant at a time when most needed. If the season a whole be considered, however, the double crop leaves less water in the soil at the end of the growing season.

3. Where cowpeas were drilled with corn at planting time there is apparently as much available nitrogen in the soil at tasseling time, when corn and peas are making their greatest growth, as is the case under straight crop treatment.

4. The lack of firing of corn on plots seeded to cowpeas, as compared with corn alone, may be due to the greater amount of available moisture in the soil under the former oropping system.

\section{PART II}

1. That compeas tend to maintain the friability of loose and compact seed beds.

2. While cowpeas on the land take more water from the soil than evaporates from uncultivated adjacent plots, the removal of water is from bel ow the second foot. 



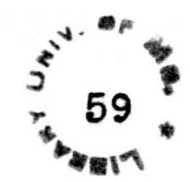

3. Iand plowed and left uncropped, or plowed and seeded to cowpeas, will leave more nitrates in the soil at the end of the season than will unplowed land similarly treated.

\section{PART III}

1. Continuous oropping to wheat and cowpeas leaves the soil in such a condition that an extract of same is deleterious to wheat plants.

2. In so far as we have gone, investigations with moisture,

regard to bacterial activity, acidity, Llant food supply, and toxic properties of this particular soil have indicated that, while not any one of the factors is capable of producing the existing infertility of land continuously cropped to wheat and compeas, some, or all of the above factors working together may produce this effect. 









\section{8. วแ11 $x(4)$}


